\title{
LH RECEPTORS AND STEROIDOGENESIS IN DISTINCT POPULATIONS OF LEYDIG CELLS *
}

\author{
Anita H. Payne, $\nmid+$ Peter J. O’Shaughnessy, $\ddagger$ David J. Chase, $\dagger$ \\ Gretchen E. K. Dixon, $\S$ and A. Kent Christensen $\S$ \\ Reproductive Endocrinology Program \\ Departments of $\dagger$ Obstetrics and Gynecology, \\ $\$$ Biological Chemistry, and \$ Anatomy \\ The University of Michigan \\ Ann Arbor, Michigan 48109
}

\section{INTRODUCTION}

Luteinizing hormone ( $\mathrm{LH}$ ) has been shown to be the only hormone essential for maintenance of testicular testosterone production. ${ }^{1}$ LH mediates its effect on testicular steroidogenesis by binding to high affinity receptors in the plasma membrane of Leydig cells. In recent years, numerous investigators have reported that in vivo administration of $\mathrm{LH}$ or human chorionic gonadotropin (hCG) results in the reduction of the number of testicular $\mathrm{LH}$ receptors ${ }^{1-7}$ accompanied by a decrease in testosterone production $1,4,6,7$ in response to subsequent stimulation by LH or hCG. Studies from our laboratory, however, have demonstrated that changes in $\mathbf{L H}$ receptor number may be dissociated from changes in LH-stimulated testosterone production following in vivo treatment with gonadotropins. ${ }^{1}$ We observed that only a single high dose of LH, $100 \mu \mathrm{g}$ or greater, caused a decrease in testicular responsiveness, whereas twice daily injections of $\mathrm{LH}$ for six days or longer were accompanied by a time-related increase in in vivo testicular testosterone secretion in response to a subsequent stimulatory dose of LH. The LH-induced loss of testicular LH receptors was similar in rats that received a single high dose of $\mathbf{L H}$ and in rats that received twice daily injections. These observations indicate that different modes of in vivo LH treatment have markedly different effects on testicular responsiveness to subsequent $\mathrm{LH} / \mathrm{hCG}$ stimulation. Interpretation of these results, however, is complicated by the possibility that chronic pituitary hormone treatment may change (1) sensitivity of the Leydig cells to subsequent LH stimulation, ( 2 ) secretion or clearance rate of testosterone, and/or (3) total number of Leydig cells. To distinguish among these possibilities, changes in Leydig cell $\mathrm{LH}$ receptor concentration and responsiveness to $\mathrm{LH}$ were assessed in the same cells after different modes of in vivo hormone treatment.

Using Metrizamide gradient centrifugation to separate dispersed testicular cells, we found evidence for two distinct populations of Leydig cells. ${ }^{8}$ Leydig cells of these two populations contain similar numbers of LH receptor sites but exhibit marked differences in testosterone production in response to in vitro

* This work was supported by National Institutes of Health Grants HD-04064 and HD-08538 to A. H. Payne and HD-12349 to A. K. Christensen. P. J. O'Shaughnessy is supported by Ford Foundation Training Grant 700-0635B; D. J. Chase and G. E. K. Dixon are supported by National Institutes of Health Training Grant 5T23HD-07048. 
stimulation by hormone or dibutyryl cyclic AMP. These differences are associated with differences in the activities of steroidogenic enzymes associated with the smooth endoplasmic reticulum. Studies of the role of these two populations of Leydig cells in the regulation of testosterone synthesis in response to in vivo and in vitro gonadotropin treatment will be described.

\section{Isolation and Separation of Leydig Cells}

A relatively quick method for the separation of interstitial tissue webs from seminiferous tubules of rat testes was developed while searching for a reliable method of obtaining purified Leydig cells. ${ }^{9}$ This method involves a short ( $5 \mathrm{~min}$ ) incubation of decapsulated testes with collagenase at $34^{\circ} \mathrm{C}$ followed by removal of seminiferous tubules from interstitial tissue webs. When examined by light microscopy, these isolated interstitial tissue webs were found to be essentially free of contaminating germ cells. ${ }^{9}$ This method for isolation of interstitial tissue was used to obtain purified Leydig cells for studies of LH receptors and Leydig cell responsiveness to $\mathrm{LH} / \mathrm{hCG}$. While evaluating different methods of purifying Leydig cells, we found evidence for the existence of two distinct populations of Leydig cells. Centrifugation of collagenase-dispersed cells from whole testes or from isolated interstitial tissue of mature rats in $0-40 \%$ Metrizamide gradients yielded two distinct peaks of Leydig cells, as identified by specific binding of $\left[{ }^{125} \mathrm{I}\right] \mathrm{hCG}$. One population (I) was found in fractions with a density of $1.085-1.117 \mathrm{~g} / \mathrm{cm}^{3}$ and the other population (II) was found in fractions with a density of $1.128-1.145 \mathrm{~g} / \mathrm{cm}^{3}$ (FIGURes 1 and 2). A major peak of cells with a small amount of $\left[{ }^{125} I\right]$ hCG binding was found only in fractions with a density of $1.055-1.065 \mathrm{~g} / \mathrm{cm}^{3}$ in gradients of dispersed cells from whole testes (FIGURE 1). The vast majority of cells in this peak are germ cells.

To assess if. Leydig cells found in peak I represented cells damaged by the collagenase treatment, cells representing peak II from a first Metrizamide gradient were combined, washed, and separated into two aliquots. One aliquot was subjected to a second treatment with collagenase under conditions identical to the original collagenase treatment, while the second aliquot was incubated in the same manner in the absence of collagenase. These aliquots of cells were then recentrifuged in separate Metrizamide gradients, and the distribution of Leydig cells in these gradients was determined by measuring specific binding of $\left[{ }^{125} \mathrm{I}\right] \mathrm{hCG}$ in individual one-ml fractions. As seen in FIGURE 3, the second collagenase treatment did not result in a shift of Leydig cells from peak II to peak I, indicating that peak I Leydig cells are not damaged cells.

When fractions representing population I and population II Leydig cells were recentrifuged in Metrizamide gradients, the majority of Leydig cells (indicated by $\left.{ }^{125} \mathrm{I}\right] \mathrm{hCG}$ binding) appeared in the same fractions as they had in the first gradient centrifugation. ${ }^{8}$ These data indicate that the two populations of Leydig cells must differ as to size, shape, and/or density.

In order to improve the separation of populations I and II Leydig cells, a discontinuous gradient of Metrizamide has been used in our most recent studies. This gradient consists, from bottom to top, of $5 \mathrm{ml} 27 \%, 10 \mathrm{ml} 20 \%$, and $10 \mathrm{ml} \mathrm{11 \%} \mathrm{Metrizamide} \mathrm{dissolved} \mathrm{in} \mathrm{Medium} 199$ containing $0.1 \%$ BSA (bovine serum albumin). The percentages of Metrizamide used in the discontinuous gradient were based on those calculated from the refractive indices of 


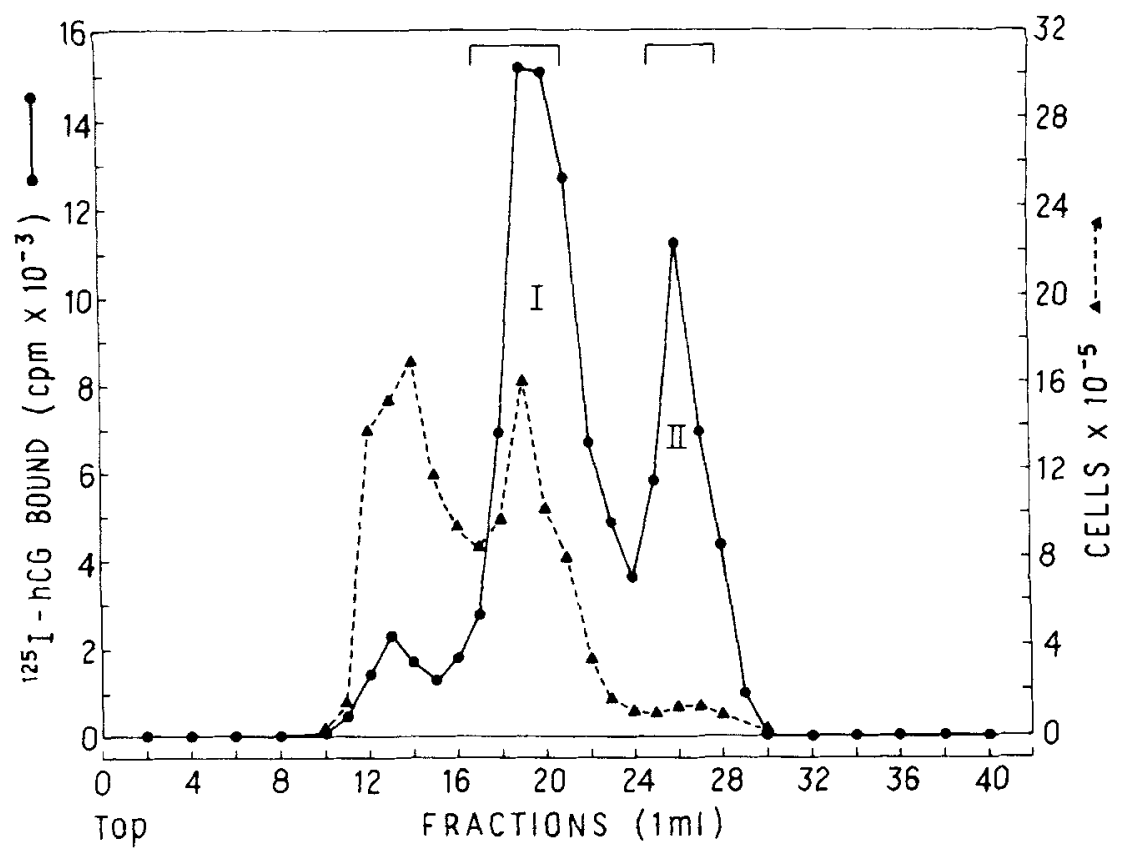

Figure 1. Sedimentation profile of dispersed cells from whole rat testes in a density gradient of $0-40 \%$ Metrizamide. Cells obtained by collagenase treatment of decapsulated testes were layered on a Metrizamide gradient. After centrifugation for $5 \mathrm{~min}$ at $3300 \times g, 1-\mathrm{ml}$ fractions were collected. Specific binding of [ ${ }^{[25}$ I] hCG to cells was determined by incubating aliquots of cells from the indicated fractions with a saturating concentration of $\left[^{125} \mathrm{I}\right] \mathrm{hCG}$ for $90 \mathrm{~min}$ at $34^{\circ} \mathrm{C}(\mathrm{O}-\mathrm{C})$. The number of total cells in each fraction was measured in a Coulter counter $(\mathbf{\Delta}--\mathbf{A}) .^{8}$ (From Payne et al. ${ }^{8}$ By permission from Endocrinology.)

fractions collected from $0-40 \%$ continuous gradients of Metrizamide. FIGURE 4 illustrates the separation of germ cells and populations I and II Leydig cells after centrifugation for $5 \mathrm{~min}$ at $3300 \times \mathrm{g}$ in a discontinuous gradient. The majority of the germ cells do not enter the gradient and were found in fraction 2. Population I Leydig cells are found in fractions $10-15$ with a refractive index of 1.3510-1.3603, while population II Leydig cells are found in fractions 20 to 24 with a refractive index $1.3629-1.3699$.

As discussed below, population I may be further divided into two subpopulations of Leydig cells that differ in response to in vitro hCG stimulation. These subpopulations are referred to as population IA (fractions 10-12) and population IB (fractions 13-15). When fractions 10-12 (IA) and fractions 13-15 (IB) were recentrifuged in separate 0 to $40 \%$ continuous Metrizamide gradients, the $\left[{ }^{125}\right.$ I]hCG binding peak of population IA was found at fraction 19 and the peak of population IB was found at fraction 21 (Figure 5). Thus, population IB does not represent a mixture of populations IA and II Leydig cells as no Leydig cells were demonstrable by [ $\left.{ }^{125}\right]$ hCG binding in fractions 25 to 29 , the fractions that normally contain population II Leydig cells (FIGURES 1 and 2). 


\section{Identification of Leydig Cells}

Leydig cells in each population were identified by histochemical staining for $3 \beta$-hydroxysteroid dehydrogenase as previously described. ${ }^{8}$ Non-Leydig cells were identified by a counterstain with eosin. Cells were examined by light microscopy and total cells and cells containing dark purple formazan deposits were counted. Cells that stained purple, indicating the presence of $3 \beta$-hydroxysteroid dehydrogenase, were considered Leydig cells. From total cell counts obtained with a Coulter counter and from the percent Leydig cells obtained by staining, the number of Leydig cells in a sample was determined. This procedure allows us to express data per number of Leydig cells. Confirmation that only cells that stain positive for $3 \beta$-hydroxysteroid dehydrogenase specifically bind $\left[{ }^{125} \mathrm{I}\right] \mathrm{hCG}$ was obtained by autoradiography. Cells from fractions containing the two populations of Leydig cells were incubated with a saturating concentration of [125I]hCG alone and together with an excess of nonradioactive hCG, subjected to the histochemical reaction for $3 \beta$-hydroxysteroid dehydrogenase, processed for autoradiography, and counterstained with eosin. Examination of slides by light microscopy indicated that all cells that were $3 \beta$-hydroxy-

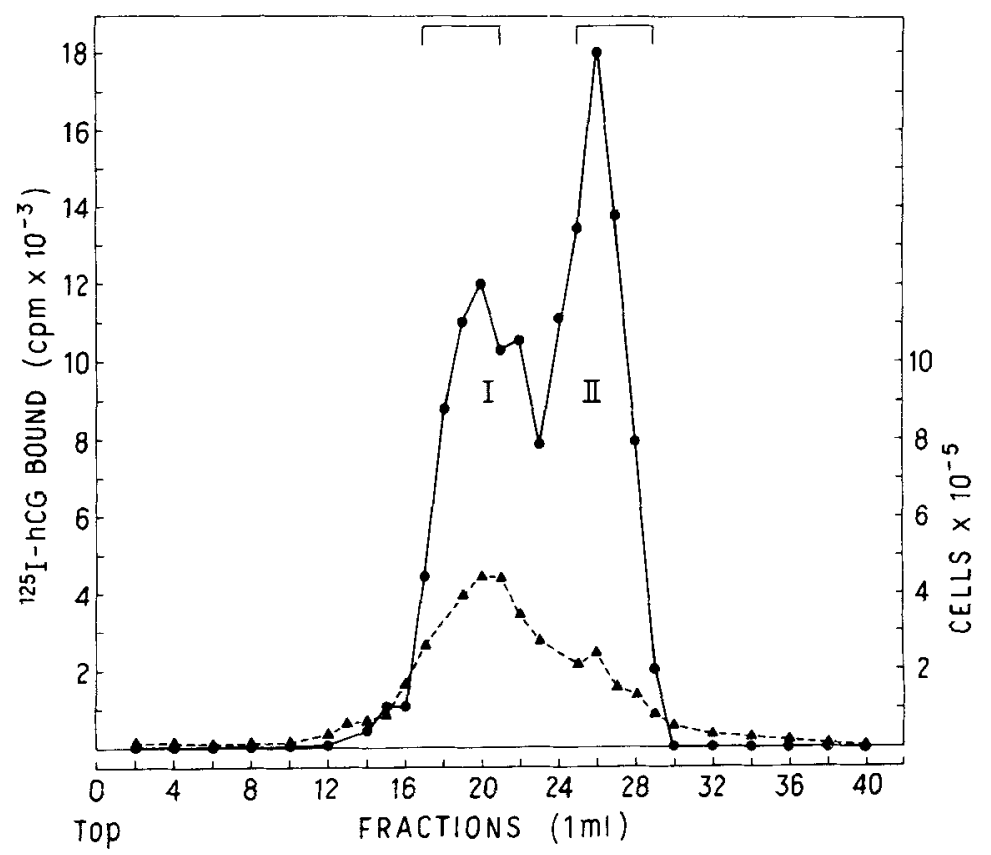

FIGURE 2. Sedimentation profile of dispersed cells from isolated interstitial tissue of rat testes in a density gradient of $0-40 \%$ Metrizamide. Cells obtained by collagenase treatment of isolated interstitial tissue were layered on a Metrizamide gradient. After centrifugation for $5 \mathrm{~min}$ at $3300 \times \mathrm{g}, 1-\mathrm{ml}$ fractions were collected. Specific binding of $\left.{ }^{\left[{ }^{25}\right.}\right] \mathrm{hCG}(\boldsymbol{-})$ and the total number of cells $\left(\boldsymbol{\Delta}-\mathbf{A}^{-}\right)$were determined in aliquots from the indicated $1-\mathrm{ml}$ fraction. The bars $(-)$ indicate the fractions combined from peaks I and II, respectively for further purification in a second Metrizamide gradient. ${ }^{8}$ (From Payne et al. ${ }^{8}$ By permission from Endocrinology.) 


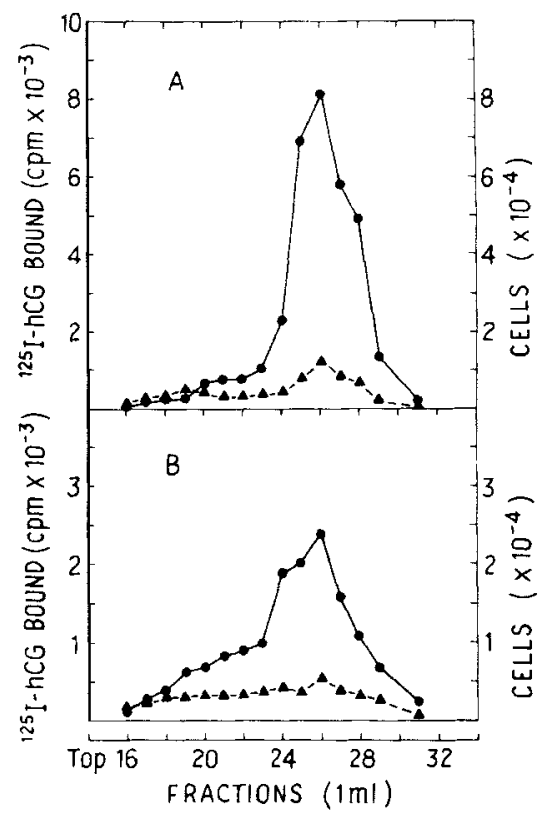

Figure 3. Sedimentation profile of cells from fractions 25-29 (peak II) subjected to additional treatment without collagenase (A) and with collagenase (B). Cells from fractions 25-29 previously obtained by Metrizamide gradient centrifugation were combined, washed, and separated into two aliquots. A. Cells in medium 199 with $0.1 \% \mathrm{BSA}$ were incubated for $20 \mathrm{~min}$ at $37^{\circ} \mathrm{C}$, washed, and reapplied to a second Metrizamide-gradient centrifugation. B. Cells in medium 199 with $0.1 \%$ BSA containing collagenase $(0.25 \mathrm{mg} / \mathrm{ml})$ were incubated for $20 \mathrm{~min}$ at $37^{\circ} \mathrm{C}$, washed, and reapplied to a second Metrizamide-gradient centrifugation. After centrifugation, $1-\mathrm{ml}$ fractions were collected and the specific binding of $\left[{ }^{125} \mathrm{I}\right] \mathrm{hCG}(-1)$ and the total number of cells $(\boldsymbol{\Delta}-\boldsymbol{\Delta})$ were determined in each $1-\mathrm{ml}$ fraction between fractions $16-31 .^{8}$ (From Payne et al. ${ }^{8}$ By permission from Endocrinology.)

steroid dehydrogenase-positive exhibited grains produced by specific binding of $\left.{ }^{\left[{ }^{125}\right.} \mathrm{I}\right] \mathrm{hCG}$. Conversely, all cells that showed specific binding of $\left[{ }^{125} \mathrm{I}\right] \mathrm{hCG}$ contained formazan deposits. Essentially no grains were associated with celis incubated with an excess of unlabeled hCG (unpublished observations).

\section{LH Receptor Sites}

The number of $\mathrm{LH} / \mathrm{hCG}$ receptor sites and the hCG-binding affinity were determined for both populations of Leydig cells obtained from a second centrifugation in a continuous Metrizamide gradient. ${ }^{\circ}$ Scatchard analysis of hCG binding to cells obtained from isolated interstitial tissue indicated a single class of binding sites for both populations of cells with no apparent difference in the binding affinity $\left(K_{a}\right)$ (FIGURE 6). $\$$ The $K_{a}$ was $0.64 \times 10^{10} \mathrm{M}^{-1}$ and $0.67 \times 10^{10} \mathrm{M}^{-1}$ for populations I and II Leydig cells, respectively. Binding capacity, when expressed per total cells, was considerably greater for population 
II cells than for population I cells (FIGURE 6) because the majority of nonLeydig interstitial cells were found in fractions containing population I Leydig cells. When binding capacity was expressed per Leydig cell (as identified histochemically by the presence of $3 \beta$-hydroxysteroid dehydrogenase), no significant difference was observed between the two populations. Binding capacity, expressed as femtomoles per $10^{6}$ Leydig cells, was $86 \pm 20$ (mean $\pm \mathrm{SE}, n=3$ ) and $91 \pm 21(n=3)$ for Leydig cell population I and II, respectively. ${ }^{8}$ This is equivalent to approximately 50,000 binding sites per Leydig cell.

\section{Leydig Cell Responsiveness}

Responsiveness to hCG was determined in each population of Leydig cells, obtained from isolated interstitial tissue webs, using the same fractions that

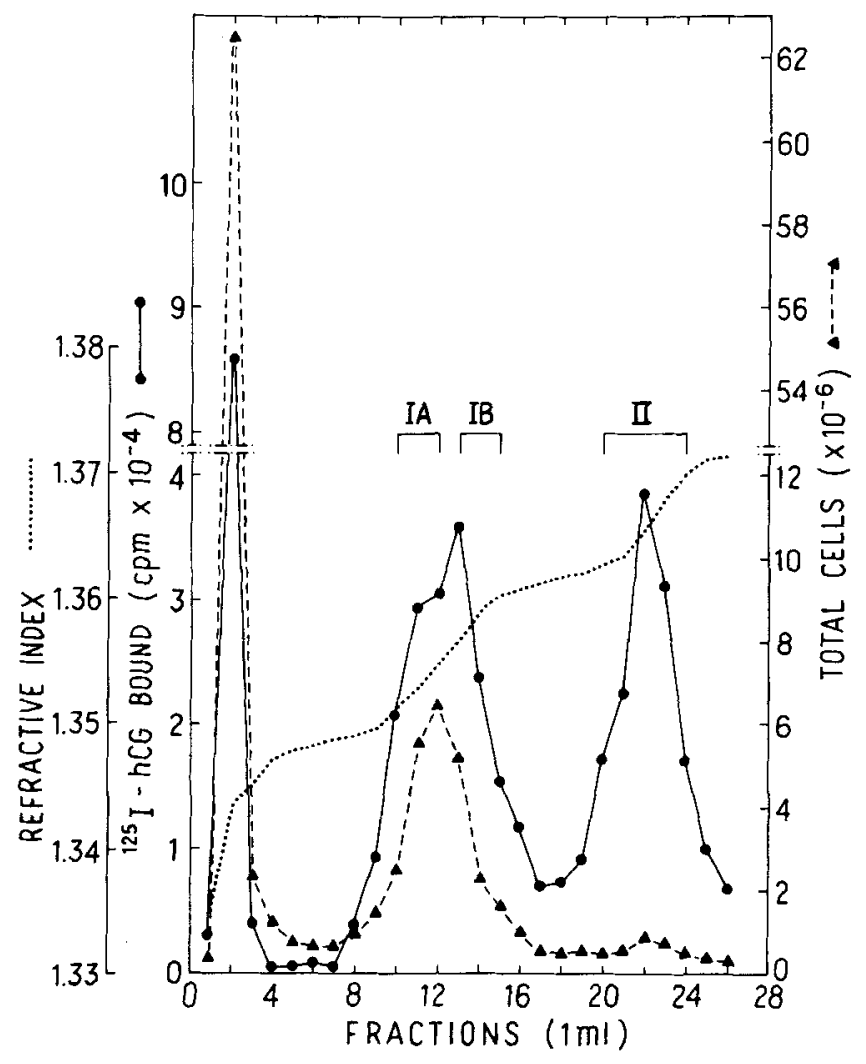

FIGURE 4. Sedimentation profile of dispersed testicular cells following centrifugation at $3300 \times \mathrm{g}$ for $5 \mathrm{~min}$ in a discontinuous Metrizamide gradient (from bottom to

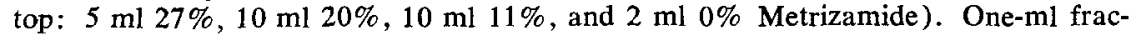
tions were collected from the top of the gradient. Specific binding of $\left.{ }^{125} I\right] \mathrm{hCG}$ $(\mathbf{O})$ to cells and total cell numbers $(\mathbf{\Delta}-\mathbf{\Delta})$ in each fraction were determined as described for FIGURE 1. Refractive index $(\cdots)$ in each fraction of Metrizamide solution was determined after centrifugation to remove cells. 


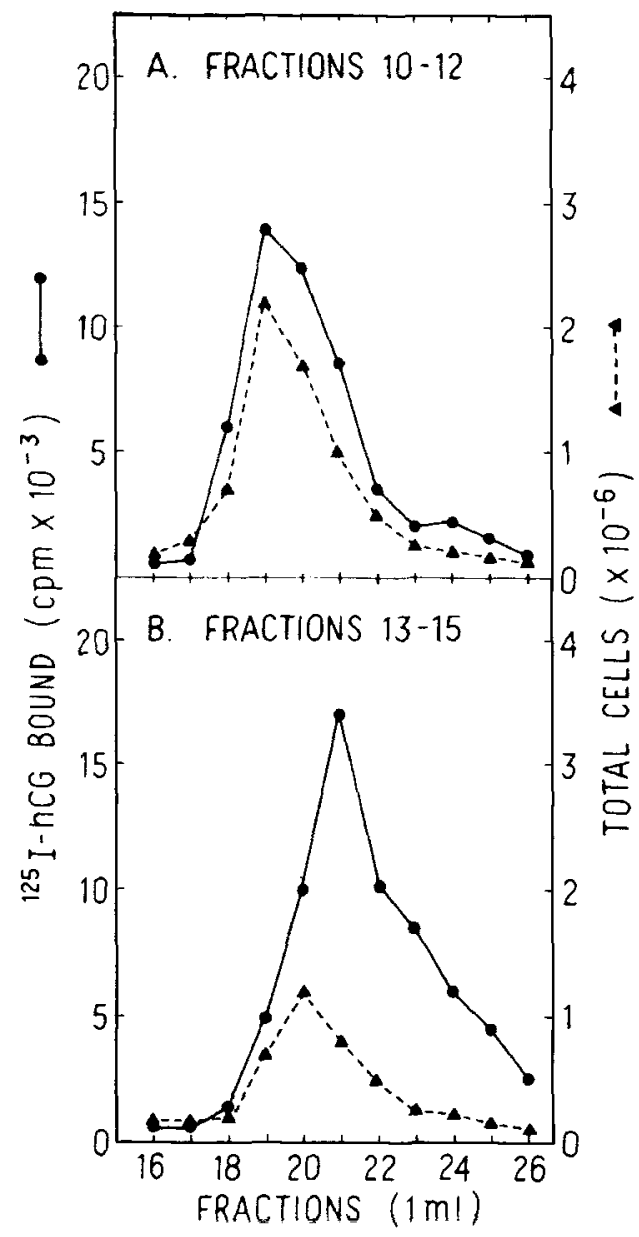

FIGURE 5. Sedimentation profile of population IA and population IB cells following centrifugation for $5 \mathrm{~min}$ at $3300 \times \mathrm{g}$ in separate, continuous $0-40 \%$ Metrizamide gradients. Cells from fractions $10-12$ (A) and fractions 13-15 (B) were combined following centrifugation of dispersed testicular cells in a discontinuous Metrizamide gradient as described in Figure 4. Cells representing IA and IB were then subjected to a second centrifugation in separate, continuous $0-40 \%$ Metrizamide gradients and $1-\mathrm{ml}$ fractions were collected from the top of the gradient. Total cell number $(\boldsymbol{\Lambda}-\boldsymbol{\Delta})$ and $\left[{ }^{125} I\right] \mathrm{hCG}$ binding $(\boldsymbol{O})$ in each fraction were determined. ${ }^{23}$

were used for the hCG binding studies. During a $3-\mathrm{h}$ incubation in the absence of hCG, testosterone production (expressed as nanograms of testosterone per fmol of LH receptor sites) was similar in the two populations of Leydig cells. With increasing concentrations of hCG, population I Leydig cells responded with only a small increase in testosterone production. In sharp contrast, testosterone production in population II Leydig cells was increased markedly in the presence of hCG, with maximal production observed at $3 \mathrm{pM} \mathrm{hCG}$ (FIGURE 7)..$^{s}$ To determine whether the two populations of Leydig cells differed 
in their capacity to respond to dibutyryl cyclic AMP, cells were incubated with increasing concentrations of dibutyryl cyclic AMP (0.25-2 mM) (Figure 8). As observed with hCG, testosterone production in population II Leydig cells was markedly greater than in population I Leydig cells.

Similar differences in testosterone production in response to increasing concentrations of hCG were observed during incubations of population I and population II Leydig cells obtained from whole testes after Metrizamide-gradient centrifugation. As seen with Leydig cells obtained from isolated interstitial tissue, the two populations exhibited similar concentrations of LH receptor sites per $10^{6}$ Leydig cells (FIGURE 9). Testosterone production in Leydig cell population II increased from 15 to $250 \mathrm{ng} / 10^{\circ}$ Leydig cells in the presence of hCG. In contrast, maximum testosterone production in population I was only $80 \mathrm{ng} / 10^{6}$ Leydig cells (FIGURE 9). Maximum production of testosterone was observed at similar concentrations of hCG in the two populations of Leydig cells.

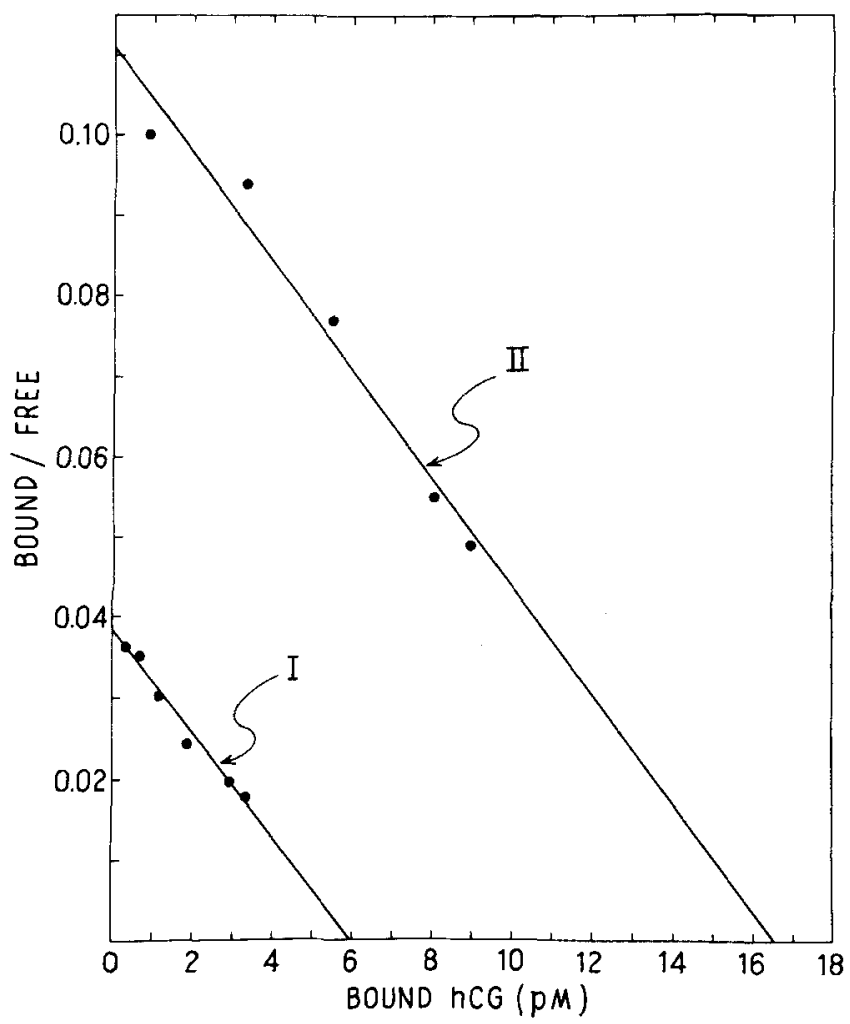

FIGURE 6. Scatchard plot of hCG-binding data derived from the incubation of interstitial cells from fractions 17-21 of peak I and from fractions 25-29 of peak II obtained after a second Metrizamide-gradient centrifugation. The specific binding of $\left[{ }^{2 \pi} I\right] h C G$ was determined by incubating aliquots of cells from each peak with increasing concentrations of $\left[{ }^{125} \mathrm{~J}\right] \mathrm{hCG}$ for $90 \mathrm{~min}$ at $34^{\circ} \mathrm{C}$. A representative plot of three separate experiments is shown. (From Payne et al. ${ }^{\circ}$ By permission from Endocrinology.) 


\section{Effects of $L H$ and $h C G$ Treatment on Leydig Cell Responsiveness and LH Receptor Concentration}

Twice-daily treatment with 6 or $12.5 \mu \mathrm{g} \mathrm{LH}$ for six days caused a marked increase in in vitro responsiveness of Leydig cell population I to hCG (FIGURE $10 \mathrm{~A}$ ). In contrast, only a small increase in testosterone production was seen in Leydig cell population II (FIGURE 10B). After six days of treatment, Leydig cell populations I and II produced similar amounts of testosterone in vitro in response to hCG. The change in in vitro responsiveness of Leydig cell population I after chronic in vivo LH treatment did not result in a change in sedimen-

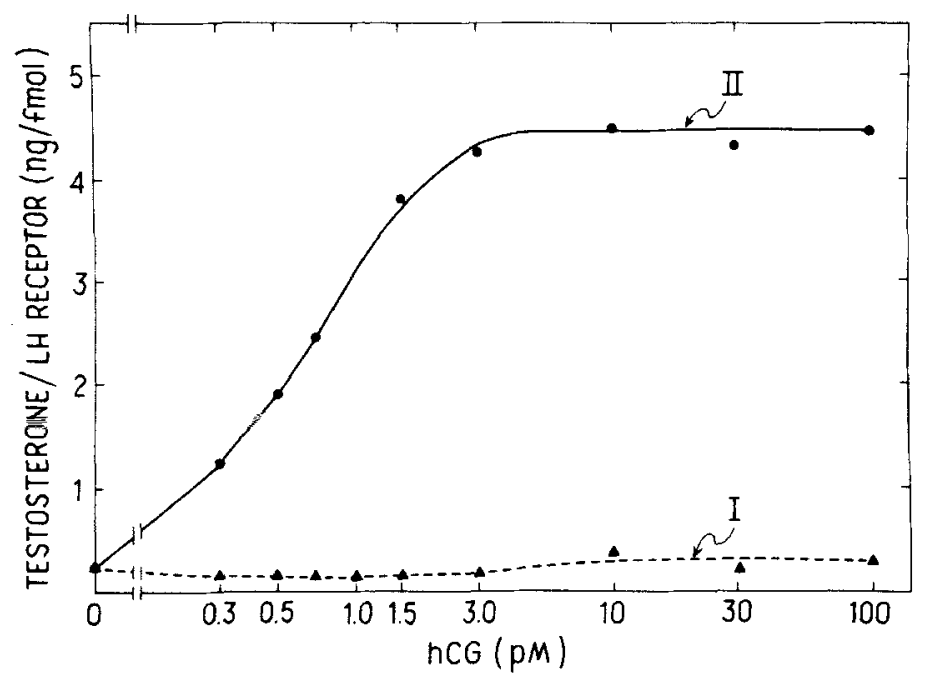

FIGURE 7. Testosterone production of Leydig cells from each peak with increasing concentrations of hCG. Aliquots of Leydig cells from fractions 17-21 of peak I or fractions 25-29 of peak II obtained after a second Metrizamide-gradient centrifugation were incubated for $3 \mathrm{~h}$ at $34^{\circ} \mathrm{C}$ with increasing concentrations of hCG. Testosterone in ceils plus medium was measured by radioimmunoassay (RIA). Separate aliquots from each peak were incubated with a saturating concentration of [ $\left.{ }^{125} \mathrm{I}\right] \mathrm{hCG}$ to measure $\mathrm{LH}$ receptor concentration. Testosterone production is expressed as nanograms of testosterone per fmol LH receptor sites. Each point represents the mean of values obtained in two separate experiments. The range of values is indicated, except where the range is smaller than the dimensions of the symbol. (From Payne et al. By permission from Endocrinology.)

tation of these Leydig cells when subjected to centrifugation in a Metrizamide gradient. The number of $\mathrm{LH}$ receptors was decreased in both populations of Leydig cells following the in vivo treatment with LH. ${ }^{10}$

The effect of a single subcutaneous injection of $150 \mu \mathrm{g} \mathrm{LH}$ on in vitro testosterone production in response to hCG, $72 \mathrm{~h}$ later, is illustrated in Figure 11A. This dose, which is equal to the total amount that was administered in the twice-daily regimen of $12.5 \mu \mathrm{g}$ for six days, resulted in losses of $\mathrm{LH}$ receptor sites of $57 \%$ and $79 \%$ in Leydig cell populations I and II, respectively. This treatment had no effect on in vitro responsiveness to hCG in population I 


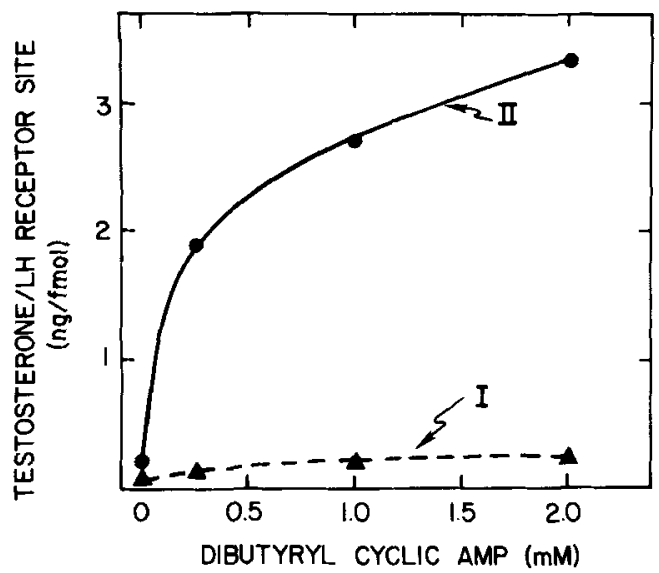

Figure 8. Testosterone production of Leydig cells from each peak with increasing concentrations of dibutyryl cyclic AMP. Leydig cells from each peak (as described for FIgURE 7) were incubated for $3 \mathrm{~h}$ at $34^{\circ} \mathrm{C}$ with increasing concentrations of dibutyryl cyclic AMP. Testosterone in cells plus medium was measured by RIA. Separate aliquots from each peak were incubated with a saturating concentration of $\left[{ }^{25} \mathrm{I}\right] \mathrm{hCG}$ to measure LH receptor concentration. Testosterone production is expressed as nanograms of testosterone per fmol LH receptor sites. Each point represents the mean of duplicate incubations.

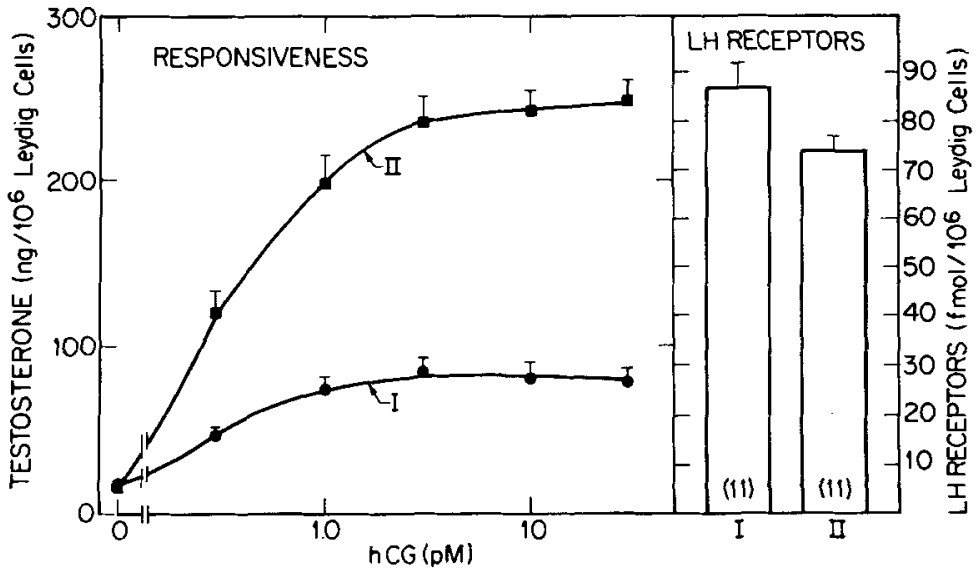

FIGURE 9. Number of $\mathbf{L H}$ receptor sites and testosterone synthesis in response to hCG in two populations of Leydig cells. For testosterone production, duplicate aliquots of Leydig cells from fractions 17-21 (population I) or from fractions 25-28 (population II) obtained after Metrizamide gradient centrifugation were incubated for $3 \mathrm{~h}$ at $34^{\circ} \mathrm{C}$ with increasing concentrations of hCG. Testosterone in cells plus medium was measured by RIA. Each point represents the mean \pm SE of 11 separate experiments. The number of LH receptor sites, expressed in femtomoles per $10^{6}$ Leydig cells, was measured by incubating separate duplicate aliquots of each population with saturating concentration of $\left[{ }^{225} \mathrm{I}\right] \mathrm{hCG}$ for $90 \mathrm{~min}$ at $34^{\circ} \mathrm{C}$. Results are the mean of 11 separate experiments. ${ }^{10}$ 

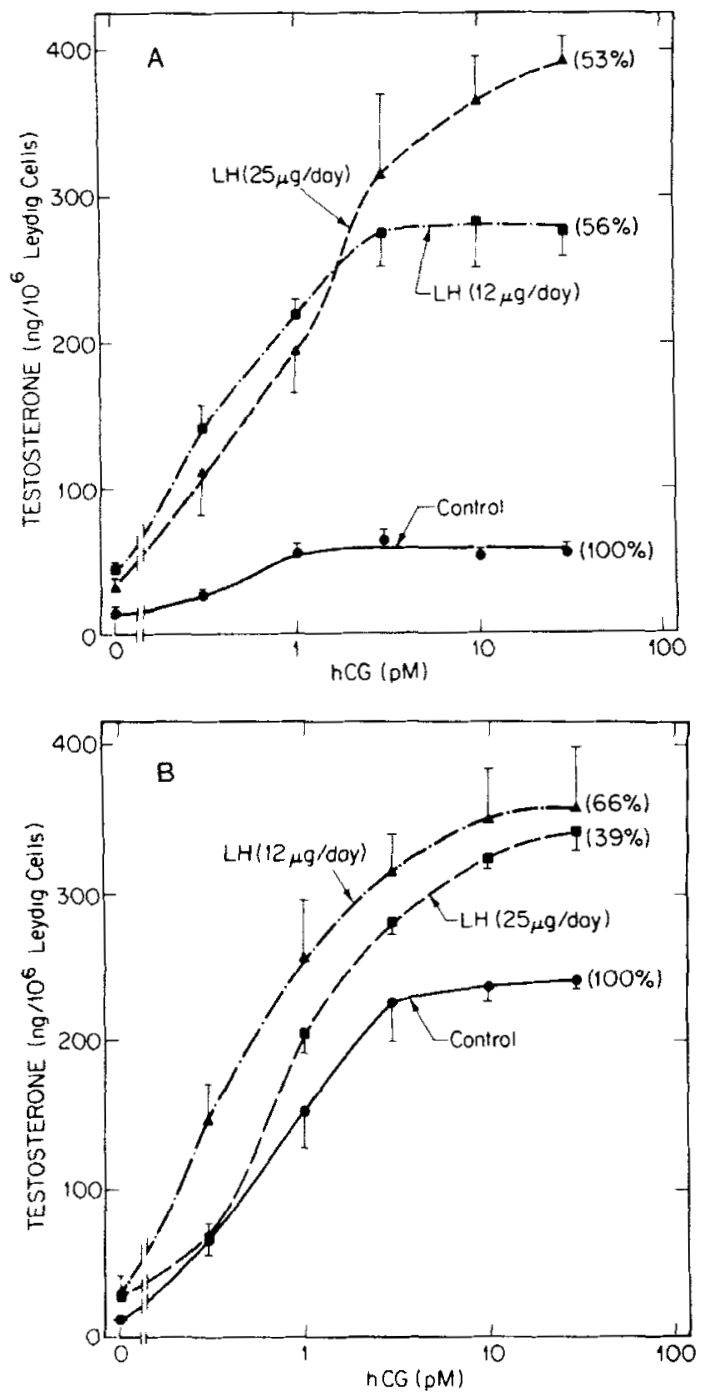

FIgURE 10. Testosterone production and LH receptor sites in populations $I$ and II Leydig cells. Rats were injected subcutaneously twice daily for six days with either saline (O), $6 \mu \mathrm{g}(\mathbf{Q})$, or $12.5 \mu \mathrm{g}$ ( $\mathbf{A}$ ) of LH. Animals were killed on day 7 and Leydig cells from fractions 17 to 21 , population 1 (A), or from fractions 25 to 28 , population II (B), were incubated in duplicate as described in the legend to FIgure 9. Each point represents the mean $\pm \mathrm{SE}$ of data from two separate experiments. The number in parentheses represents the percentage of $\mathrm{LH}$ receptor sites per $10^{\circ} \mathrm{Leydig}$ cells relative to control. ${ }^{10}$ 
Leydig cells but markedly decreased maximal testosterone production in response to hCG in population II Leydig cells (Figure 11B). Maximum testosterone production in these Leydig cells was not affected by increasing the in vitro concentration of hCG up to $1,000 \mathrm{pM}$.
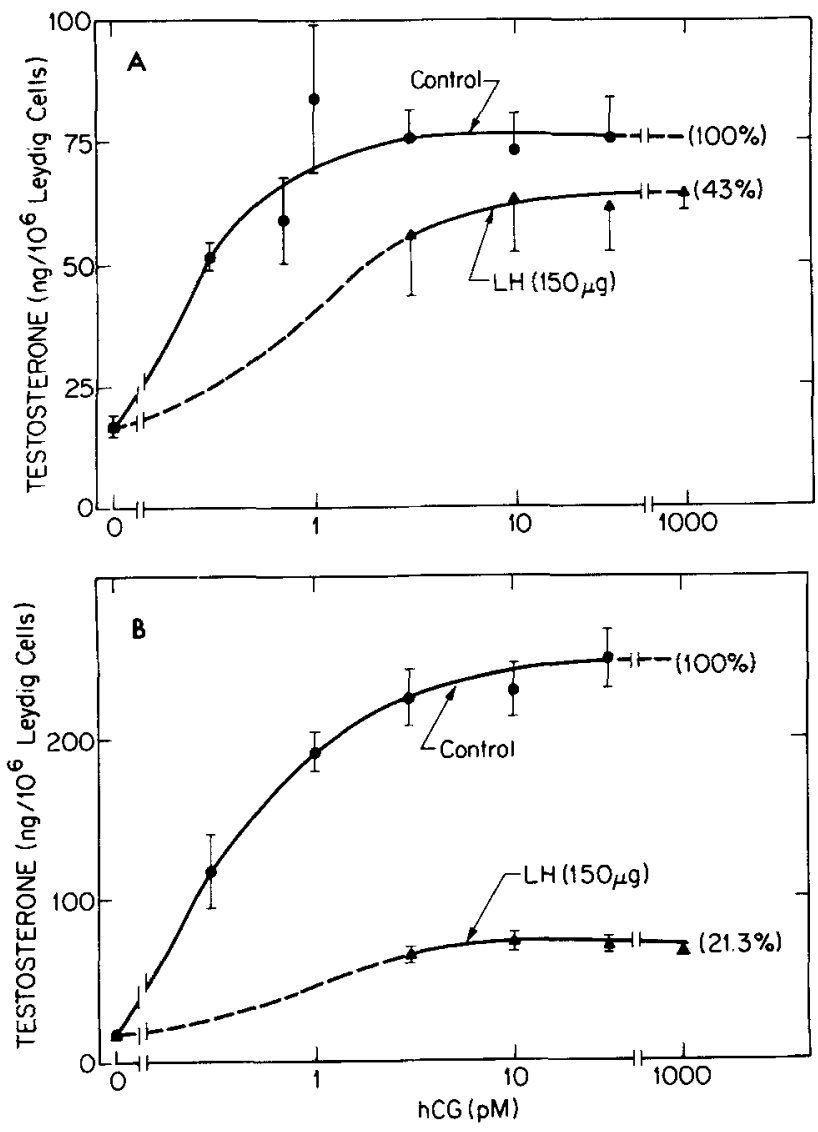

FIgURE 11. Testosterone production and LH receptor sites in populations I and II Leydig cells after a single administration of LH. Rats were injected with one subcutaneous injection of either saline (⿻) or $150 \mu \mathrm{g} \mathrm{LH}(\boldsymbol{\Delta})$. Animals were killed $72 \mathrm{~h}$ after the injection. Aliquots of Leydig cells from fractions 17 to 21, population I (A) or fractions 25 to 28 , population II (B) were incubated in duplicate as described in the legend to FIGURE 9. Each point represents the mean \pm SE of data from two separate experiments. Note the difference in the scales of the ordinates in A and B. The number in parentheses represents the percentage of LH receptor sites per $10^{\circ}$ Leydig cells relative to control. ${ }^{10}$

A single subcutaneous injection of 100 I.U. of hCG completely desensitized all Leydig cells. Receptor loss was greater than $90 \%$ in both populations and was accompanied by complete loss of responsiveness to in vitro hCG stimulation $72 \mathrm{~h}$ after the injection of the hormone. ${ }^{10}$ 
These data demonstrate that the effect of $\mathrm{LH}$ or hCG on Leydig cell steroidogenesis is dependent on the mode of administration of the hormone and does not appear to relate to loss of $\mathrm{LH}$ receptor sites. Previous reports that have indicated that gonadotropin-induced loss of testicular LH receptors is accompanied by a decrease in in vitro $\mathrm{LH} / \mathrm{hCG}$-stimulated testosterone production were based on studies using a single injection of hCG or LH.1, 4, 6, i Previous studies from our laboratory using mature male rats indicated that, although all variations of treatment with $\mathrm{LH}$ caused a loss of testicular $\mathrm{LH}$ receptors, only a single dose, $100 \mu \mathrm{g}$ or greater, was accompanied by a decrease in in vivo testicular responsiveness to a subsequent stimulatory dose of LH. Injections of $15 \mu \mathrm{g} \mathrm{LH}$, administered twice daily, for up to ten days resulted in a similar loss of testicular $\mathrm{LH}$ receptors as a single high dose of $\mathrm{LH}$, but caused a timerelated increase in in vivo testicular responsiveness. ${ }^{1}$ Similar observations were made in mature hypophysectomized rats. ${ }^{1}$ Thus, the present study as well as our previous studies clearly demonstrate that Leydig cell steroidogenic desensitization does not occur except afier a single administration of a high, nonphysiological dose of LH or hCG. Since the testis is normally exposed to only small pulsatile $\mathbf{L H}$ discharges and not to massive LH surges, LH-induced steroidogenic desensitization as described by several authors ${ }^{1,4,6,7}$ is not a likely mechanism by which Leydig cell steroid production is regulated in vivo. The demonstration that $\mathrm{LH}$ has different effects on the two populations of Leydig cells must be considered in future studies on hormonal regulation of Leydig cell function. At present, it is not known if chronic LH treatment also results in an increase in total numbers of Leydig cells as well as an increase in responsiveness of Leydig cell population I to acute LH/hCG stimulation.

\section{Steroidogenic Enzymes in Different Populations of Leydig Cells}

\section{Aromatase Activity}

Considerable controversy has existed as to which cell type in the testis is the site of estrogen synthesis. Studies by Dorrington and colleagues ${ }^{11}$ indicate that Sertoli cells from immature rats, when maintained in culture in the presence of follicle stimulating hormone (FSH) and testosterone, have the capacity to synthesize estradiol. In more recent studies it was reported that treatment of adult ${ }^{12}$ or immature ${ }^{13}$ rats with $\mathrm{LH}$ or hCG resulted in induction of testicular aromatase activity. Administration of FSH to 15-day-old rats for 3-4 days ${ }^{13}$ or to mature rats for 6 days $^{12}$ had no effect on testicular aromatase activity. These latter observations suggest that in rats 15 days or older, Leydig cells rather than Sertoli cells are the site of testicular aromatization. To investigate if isolated Leydig cells from mature rats have the capacity for aromatization and to determine if this activity can be acutely stimulated by $\mathrm{LH} / \mathrm{hCG}$, the conversion of $\left[{ }^{3} \mathrm{H}\right]$ testosterone to $\left[{ }^{3} \mathrm{H}\right]$ estradiol (aromatase activity) was studied in Leydig cell populations I and II.

Testicular cells from mature rats ( $\sim 65$ days) were separated in a $0-40 \%$ continuous gradient of Metrizamide. Fractions representing population II Leydig cells were incubated with increasing concentrations of $\left[{ }^{3} \mathbf{H}\right]$ testosterone $(0.12-1.2 \mu \mathrm{M})$ and the amount of $\left[{ }^{3} \mathrm{H}\right]$ estradiol produced during a 4 -h incubation was determined as described previously. ${ }^{12}$ Maximal aromatase activity was observed at $0.6 \mu \mathrm{M}$ testosterone (Figure 12).1. To determine if aromatase 
activity could be stimulated in vitro by hCG, Leydig cells from populations I and II were incubated with $0.6 \mu \mathrm{M}\left[{ }^{3} \mathrm{H}\right]$ testosterone and increasing concentrations of hCG (0.3-100 pM). Aromatization by population II Leydig cells was stimulated by hCG during a 4-h incubation, with maximal production of $1.8 \mathrm{ng}$ estradiol per $10^{6}$ cells observed at $10 \mathrm{pM}$ hCG (Figure 13).1.t Aromatase activity was not detectable in population I Leydig cells in the absence or in the presence of hCG. Studies of the time course of hCG stimulation of aromatization in population II Leydig cells indicated a small increase in aromatization at $1 \mathrm{~h}$ and a marked increase between 1 and $4 \mathrm{~h}$ (FIGURE 14). ${ }^{14}$

These data demonstrate that Leydig cells have the capacity to aromatize testosterone to estradiol and that this capacity is specific for population II Leydig cells. Furthermore, the observation that hCG can acutely stimulate aromatization, in the presence of a saturating concentration of testosterone, establishes that acute stimulation of testosterone synthesis and acute stimulation of aromatization are independent effects of $\mathrm{LH} / \mathrm{hCG}$ on population II Leydig

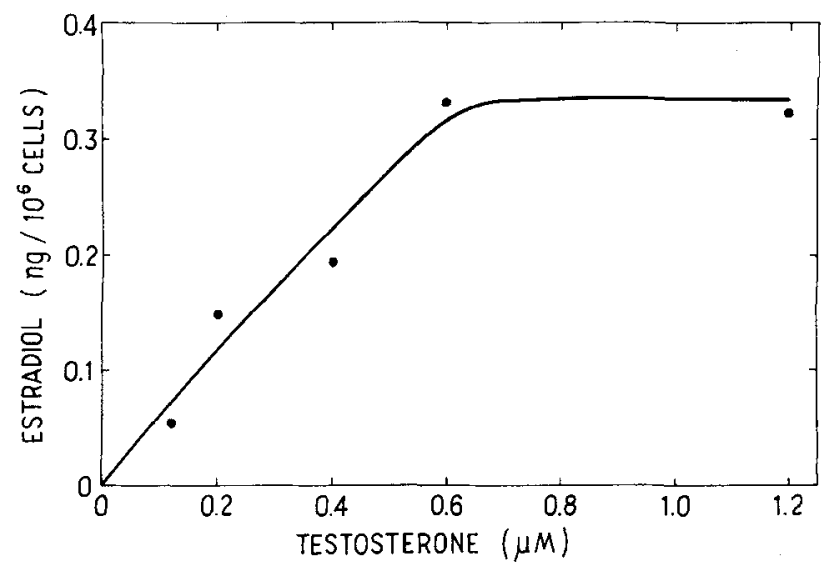

Figure 12. Effect of increasing concentrations of $\left[{ }^{3} \mathrm{H}\right]$ testosterone on aromatization by Leydig cell population II from adult rats. Approximately $3 \times 10^{5}$ cells were incubated for $4 \mathrm{~h}$ at $34^{\circ} \mathrm{C}$ under $95 \% \quad \mathrm{O}_{2} / 5 \% \quad \mathrm{CO}_{2}$ with indicated concentrations of $\left[{ }^{3} \mathrm{H}\right]$ testosterone. Each value represents the mean of duplicate incubation. ${ }^{14}$

cells in vitro. Studies by Dufau and colleagues ${ }^{15,16}$ have indicated that hCGinduced steroidogenic desensitization is caused by an increased production of estradiol in Leydig cells of hormone-treated animals. Our demonstration that aromatase activity is found only in Leydig cell population II may explain the different effects of in vivo LH treatment on responsiveness of Leydig cells of the two populations to subsequent hCG stimulation in vitro discussed earlier in this chapter.

\section{Enzymes Involved in the Conversion of $C_{21}$ to $C_{19}$ Androgens}

As discussed earlier, a pronounced difference in testosterone production was evident between the two populations of Leydig cells when cells were incubated with dibutyryl cAMP. This observation suggests that the difference in respon- 


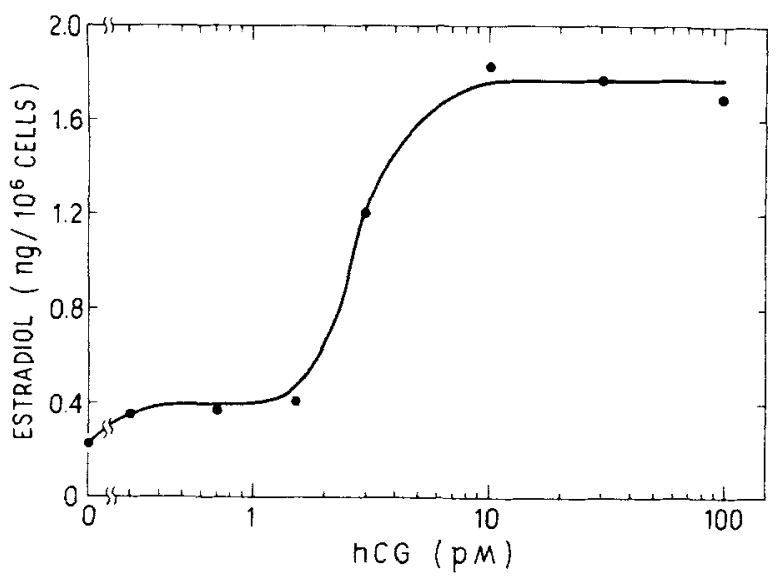

FIGURE 13. Effect of increasing concentrations of hCG on in vitro aromatization by population II Leydig cells. Approximately $3 \times 10^{5}$ cells were incubated for $4 \mathrm{~h}$ at $34^{\circ} \mathrm{C}$ under $95 \% \quad \mathrm{O}_{2} / 5 \% \mathrm{CO}_{2}$ with $0.6 \mu \mathrm{M}\left[{ }^{3} \mathrm{H}\right]$ testosterone and indicated concentrations of hCG. Each value represents the mean of duplicate incubations. ${ }^{14}$

siveness of the two populations of Leydig cells is due to biochemical events distal to LH/hCG binding and stimulation of cyclic AMP production. We therefore set out to measure the activities of several of the key steroidogenic enzymes responsible for the production of testosterone in the different populations of Leydig cells. The enzymes $\Delta^{5}-3 \beta$-hydroxysteroid dehydrogenase-isomerase, 17-hydroxylase, $\mathrm{C}_{17}-\mathrm{C}_{20}$ lyase, and 17 -ketosteroid reductase were studied. All of these enzymes are associated with the smooth endoplasmic reticulum

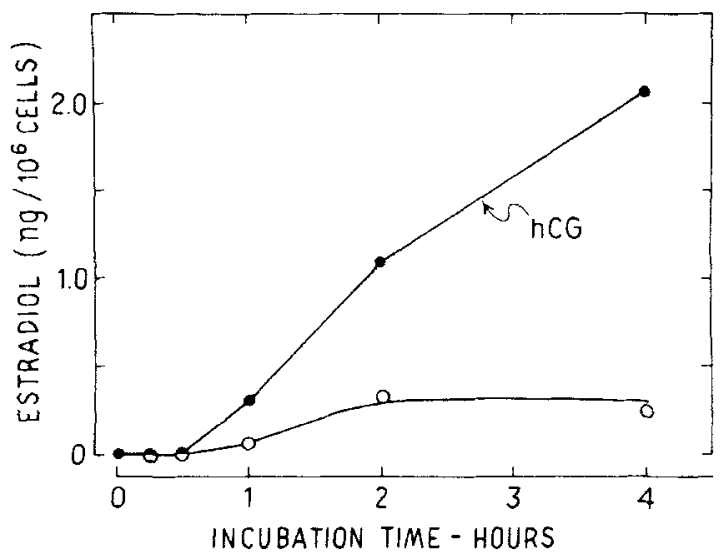

FIgURE 14. Relationship of time to in vitro hCG stimulation of aromatization by Leydig cells. Approximately $3 \times 10^{5}$ cells were incubated for the indicated time at $34^{\circ} \mathrm{C}$ under $95 \% \quad \mathrm{O}_{2} / 5 \% \quad \mathrm{CO}_{2}$ with $0.6 \mu \mathrm{M}\left[{ }^{3} \mathrm{H}\right]$ testosterone in the absence $(\mathrm{O})$ or in the presence (O) of $30 \mathrm{pM}$ hCG. Each value represents the mean of duplicate incubations. ${ }^{14}$ 
(SER) of the rat Leydig cells, ${ }^{17}$ and a recent report has shown that species differences in testosterone production are correlated with SER volume and density. ${ }^{19}$

In these enzyme studies, Leydig cells were separated by centrifugation in a discontinuous Metrizamide gradient as described earlier in this chapter. In preliminary experiments it was found that hCG-stimulated testosterone production in individual 1-ml fractions representing population I (fractions 10-15, FIGURE 3) was markedly higher in fractions 13-15 than in fractions 10-12. This finding suggested that fractions 10-12 and 13-15 may represent different subpopulations of Leydig cells. As noted earlier, fractions 13-15 were not a mixture of populations IA and II. No difference in hCG-stimulated testosterone production was observed between individual 1-ml fractions (fractions 20-24) representing population II Leydig cells (unpublished data). In view of these findings, enzyme studies have been carried out using subpopulations IA and IB as well as population II Leydig cells.

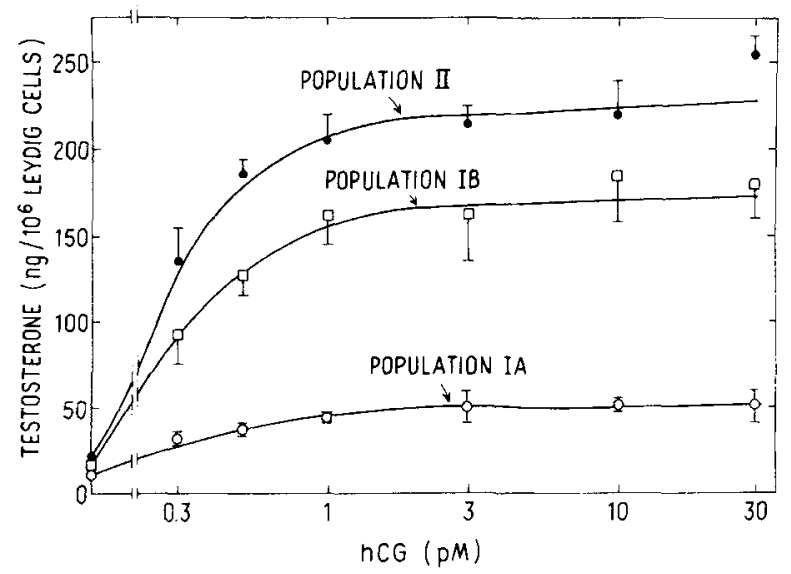

FIgURE 15. Testosterone production, in response to $\mathrm{hCG}$, in three populations of Leydig cells in vitro. Cells from populations IA $(\mathrm{O}-\mathrm{O})$, IB ( were collected from a discontinuous Metrizamide gradient and incubated for $3 \mathrm{~h}$ at $34^{\circ} \mathrm{C}$ in the presence of increasing concentrations of hCG. Testosterone concentration in cells and medium was measured by RIA. The mean \pm SE of duplicate determination is shown. Analysis of variance (not including basal testosterone production) showed that there was a significant $(P<0.001)$ difference between hCG-stimulated levels of testosterone production in populations IB and $\mathrm{II}^{23}$

Testosterone production in response to increasing concentrations of hCG in the three populations is shown in Figure 15. Population II Leydig cells produced significantly more testosterone than population IB, and both showed markedly higher production than population IA. In the presence of $30 \mathrm{pM}$ hCG, testosterone production was stimulated 12 -fold to $250 \mathrm{ng} / 10^{6}$ Leydig cells in population II, 10-fold to $180 \mathrm{ng} / 10^{6}$ Leydig cells in population IB, and 4.5 -fold to $50 \mathrm{ng} / 10^{6}$ Leydig cells in population IA. LH receptor sites, expressed as fmol per $10^{6}$ Leydig cells, were similar in the three populations; $102 \pm 6$ (mean $\pm \mathrm{SE}, n=5), 108 \pm 15(n=5)$, and $99 \pm 9(n=5)$ in Leydig cell populations IA, IB, and II, respectively.

In order to evaluate steroidogenic enzyme activities, dispersed testicular 
cells from whole testes of 60-day-old rats were separated by centrifugation in discontinuous Metrizamide gradients. Fractions 10-12, 13-15, and 20-24 were combined as populations IA, IB, and II, respectively.

The saturating substrate concentration for each enzyme activity was established in preliminary studies. The activity of $\Delta^{5}-3 \beta$-hydroxysteroid dehydrogenase-isomerase was studied in cellular homogenates by measuring the conversion of $\left[{ }^{3} \mathrm{H}\right]$ pregnenolone to $\left[{ }^{3} \mathrm{H}\right]$ progesterone in the presence of $0.5 \mathrm{mM} \mathrm{NAD}{ }^{+}$ during a 10 -min incubation. ${ }^{20}$ Since $\left[{ }^{125} \mathrm{I}\right] \mathrm{hCG}$ binding per $10^{6}$ Leydig cells was found to be essentially identical in all populations of Leydig cells, $\Delta^{5}-3 \beta$-hydroxysteroid dehydrogenase-isomerase activity was expressed as pmol progesterone produced per fmol $\left.{ }^{125} I\right]$ hCG bound. No difference in the activity of this enzyme was observed between populations IA and IB, although both of these subpopulations showed markedly higher activity than population II (TABLE 1).

The remainder of the enzyme activities were investigated in intact cell preparations. Cells were incubated for $1 \mathrm{~h}$ at $34^{\circ} \mathrm{C}$ with the appropriate ${ }^{3} \mathrm{H}$ labeled substrate. Steroids were extracted and separated as described previously. ${ }^{20}$ The 17 -hydroxylase activity was determined by measuring the conversion of progesterone to 17-hydroxyprogesterone, androstenedione, and

TABLE 1

$\Delta^{5}-3 \beta$-Hydroxysteroid Dehydrogenase-Isomerase ACTIVITY in Different Populations of Leydig Cells

\begin{tabular}{cc} 
Cell & Progesterone Formed \\
\cline { 2 - 2 } Population & $\left(\mathrm{pmol} / \text { fmol }\left[{ }^{125}\right] \mathrm{hCG} \text { bound }\right)^{*}$ \\
\hline IA & $27.09 \pm 0.19$ \\
IB & $25.59 \pm 2.91$ \\
II & $12.95 \pm 0.61$ \\
\hline
\end{tabular}

* Mean \pm SE of duplicate incubations.

testosterone. The 17-hydroxylase activity was twice as high in populations IB and II than in population IA (TABLE 2). There was no difference in activity between populations IB and II. ${ }^{23}$

The $\mathrm{C}_{17}-\mathrm{C}_{20}$ lyase activity was determined by measuring the conversion of 17-hydroxyprogesterone to androstenedione and testosterone. The $\mathrm{C}_{17}-\mathrm{C}_{20}$ lyase activity in the three populations of Leydig cells is shown in TABLE 3. The activity of this enzyme was different in all three populations of Leydig cells. Both populations IB and II showed higher activity than population IA, population IB showing 2.45-fold higher activity and population II 3.6-fold higher activity than population IA. ${ }^{23}$

The 17-ketosteroid reductase activity was determined by measuring the conversion of androstenedione to testosterone and dihydrotestosterone. As shown in TABLE 4, this enzyme activity did not differ markedly between the three populations, although activity in population IA was slightly less than in populations IB and II. ${ }^{23}$

These data demonstrate that there were distinct differences in the patterns of various steroidogenic enzyme activities among the three Leydig cell populations. The higher activity of $\Delta^{5}-3 \beta$-hydroxysteroid dehydrogenase-isomerase in populations IA and IB, compared to population II, would suggest that this 
TABLE 2

17-Hydroxylase Activity in Different Populations of Leydig Cells

\begin{tabular}{|c|c|c|c|c|}
\hline \multirow{3}{*}{$\begin{array}{c}\text { Cell } \\
\text { Population }\end{array}$} & \multicolumn{3}{|c|}{ Products Formed } & \multirow{3}{*}{$\begin{array}{c}\text {-Total } 17 \text {-Hydroxylase } \\
\text { Activity } \\
\text { (nmol/10 } \\
\text { Leydig cells) } \dagger\end{array}$} \\
\hline & $\begin{array}{l}17 \text {-Hydroxy- } \\
\text { progesterone }\end{array}$ & $\begin{array}{l}\text { Androstene- } \\
\text { dione }\end{array}$ & Testosterone & \\
\hline & \multicolumn{3}{|c|}{$\left(\mathrm{nmol} / 10^{6} \text { Leydig cells }\right)^{*}$} & \\
\hline IA & $3.28 \pm 0.01$ & $0.83 \pm 0.14$ & $0.13 \pm 0.01$ & $4.24 \pm 0.15$ \\
\hline IB & $8.45 \pm 0.40$ & $1.30 \pm 0.02$ & $0.23 \pm 0.04$ & $9.98 \pm 0.50$ \\
\hline II & $8.12 \pm 0.51$ & $1.1 \pm 0.01$ & $0.27 \pm 0.05$ & $9.46 \pm 0.53$ \\
\hline
\end{tabular}

* Mean \pm SE of duplicate incubations.

$\dagger$ 17-hydroxylase activity was determined as the sum of 17-hydroxyprogesterone, androstenedione, and testosterone formed.

TABLE 3

$\mathrm{C}_{1 \mathrm{i}}-\mathrm{C}_{21}$ Lyase activity in Different Populations of Leydig Cells

\begin{tabular}{|c|c|c|c|}
\hline \multirow[b]{2}{*}{$\begin{array}{c}\text { Cell } \\
\text { Population }\end{array}$} & \multicolumn{2}{|c|}{ Products Formed } & \multirow{2}{*}{$\begin{array}{c}\text { Total } \mathrm{C}_{1+}-\mathrm{C}_{20} \text { Lyase } \\
\text { Activity } \\
\text { (nmol/10 } \\
\text { Leydig cells) } \dagger\end{array}$} \\
\hline & \multicolumn{2}{|c|}{$\left(\mathrm{nmol} / 10^{s} \text { Leydig cells }\right)^{*}$} & \\
\hline IA & $0.96 \pm 0.01$ & $0.08 \pm 0.01$ & $1.04 \pm 0.01$ \\
\hline IB & $2.12 \pm 0.01$ & $0.43 \pm 0.03$ & $2.55 \pm 0.02$ \\
\hline II & $2.71 \pm 0.01$ & $1.05 \pm 0.05$ & $3.76 \pm 0.02$ \\
\hline
\end{tabular}

* Mean \pm S.E. of duplicate incubations.

$+\mathrm{C}_{1-}-\mathrm{C}_{20}$ lyase activity was determined as the sum of androstenedione and testosterone formed.

TABLE 4

17-Ketosteroid Reductase Activity in Different Populations of Leydig Cells

\begin{tabular}{cccc}
\hline & \multicolumn{2}{c}{ Products Formed } & $\begin{array}{c}\text { Total 17-Ketosteroid } \\
\text { Reductase Activity } \\
\text { Cell }\end{array}$ \\
\cline { 2 - 4 } Population & $\begin{array}{c}\text { Testosterone } / 10^{6} \\
\text { Leydig cells) } \dagger\end{array}$ & $\begin{array}{c}\text { Dihydrotestosterone } \\
\text { (nmol/10 Leydig cells)* }\end{array}$ & $4.92 \pm 0.16$ \\
IA & $4.15 \pm 0.15$ & $0.76 \pm 0.06$ & $6.29 \pm 0.35$ \\
IB & $5.43 \pm 0.25$ & $0.87 \pm 0.10$ & $6.34 \pm 0.02$ \\
II & $6.15 \pm 0.02$ & $0.23 \pm 0.05$ & \\
\hline
\end{tabular}

* Mean \pm S.E. of duplicate incubations.

$\dagger 17$-ketosteroid reductase activity was determined as the sum of testosterone and dihydrotestosterone formed. 
enzyme is not rate-limiting for androgen synthesis in the mature rat testis (at least in populations IA and IB) as testosterone production is highest in population II. Of the enzyme activities measured, only $\mathrm{C}_{11}-\mathrm{C}_{20}$ lyase showed a difference between all three populations of Leydig cells. Differences in the activity of this enzyme among the Leydig cell populations closely paralleled the differences in hCG-stimulated testosterone production shown in FiguRE 17. This observation suggests that the lower testosterone production seen in populations IA and IB may be, at least partly, a consequence of decreased $\mathrm{C}_{19}$-steroid production from 17-hydroxyprogesterone.

During sexual maturation of the male rat the appearance of 17 -ketosteroid reductase activity closely parallels the ability of the testis to produce testosterone in vitro. ${ }^{21}$ These results suggested that 17 -ketosteroid reductase may be ratelimiting in the immature rat. From results reported here, however, it can be seen that there is little difference in the activity of this enzyme among the three Leydig cell populations. This suggests that 17 -ketosteroid reductase is not rate-limiting in the mature rat testis. Although no major differences in 17-ketosteroid reductase activity were observed in the populations of Leydig cells, it is interesting to note that the apparent $5 \alpha$-reduction of testosterone to dihydrotestosterone shown in TABLE 4 is markedly higher in populations IA and IB than population II. The activity of testicular $5 \alpha$-reductase is at a maximum in 35-day-old rats and decreases markedly during sexual maturation. ${ }^{22}$ It is therefore possible that populations IA and IB represent "immature" Leydig cells which may differentiate during sexual maturation into population II Leydig cells. In an attempt to resolve this issue, we investigated changes in the relative number of Leydig cells in each population during sexual maturation.

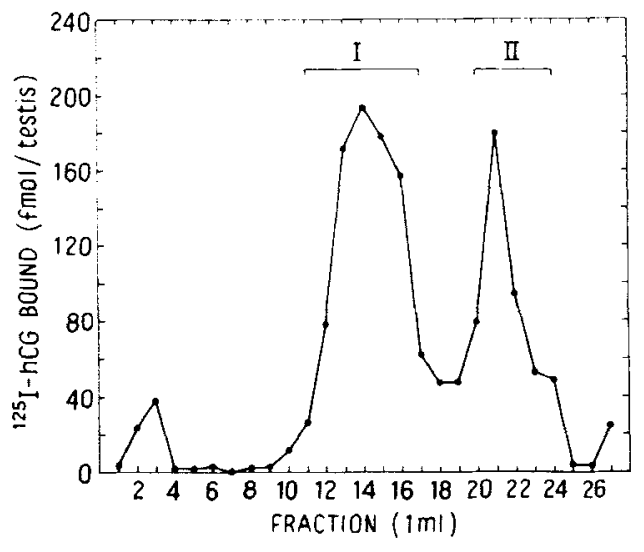

Figure 16. Profile of [' ${ }^{1 *}$ I]hCG binding in fractions collected after Metrizamide gradient centrifugation of dispersed testicular cells from 44-day-old rats. Testes were completely dissociated as described in text, centrifuged in a discontinuous gradient of Metrizamide, and specific binding of [1'in]hCG to cells was determined in one-ml fractions as described in the legend to FIGURE 1. Specific binding of $\left[{ }^{125} I\right] \mathrm{hCG}$ in each fraction was normalized to represent binding per testis. Fractions 11-17 represent population I and fractions $20-24$ represent population II Leydig cells. 


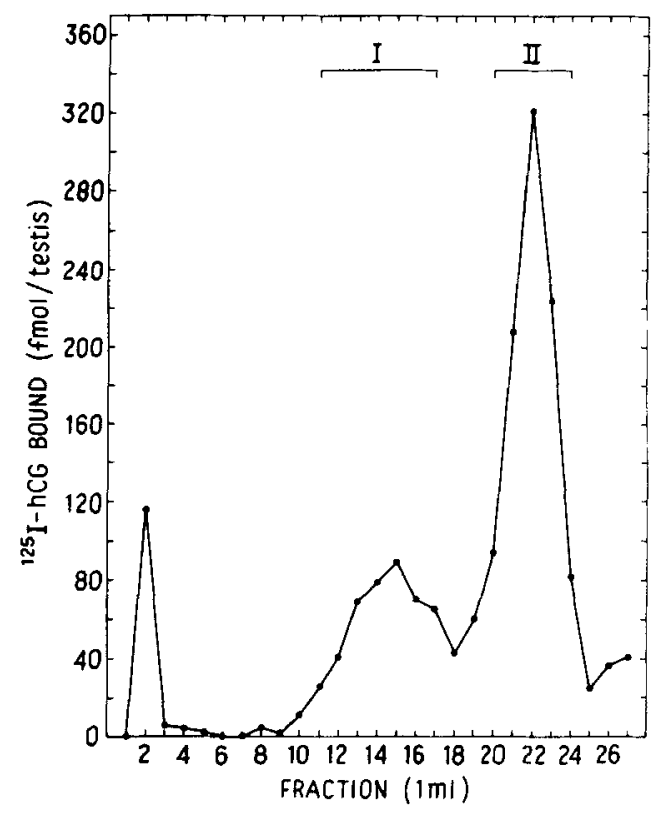

FIGURE 17. Profile of [ $\left.{ }^{[15} \mathrm{I}\right] \mathrm{hCG}$ binding in fractions collected after Metrizamide gradient centrifugation of dispersed testicular cells from 55-day-old rats. Procedures were identical to those described in the legend to Figure 16.

\section{Developmental Changes in Distribution of Leydig Cells Between Populations I and II}

Changes in the distribution of Leydig cells between populations I and II were evaluated during pubertal development. Decapsulated testes from rats between the ages of 38 and 55 days were completely dissociated by incubation for $25 \mathrm{~min}$ with collagenase $(1 \mathrm{mg} / \mathrm{ml})$ in medium containing $1.5 \mathrm{mg} / \mathrm{ml} \mathrm{BSA}$. To facilitate complete dissociation, the tissue was dispersed several times with pasteur pipettes during the incubation. Leydig cell populations I and II were separated by centrifugation in discontinuous gradients of Metrizamide. One-ml fractions were collected from the top of the gradient and specific binding of $\left[{ }^{125} \mathrm{I}\right] \mathrm{hCG}$ to cells in these fractions was determined. Since preliminary studies demonstrated that $\left.{ }^{125} I\right] \mathrm{hCG}$ binding per Leydig cell is essentially the same in both populations of Leydig cells from rats 25 days or older, changes in number of Leydig cells and in distribution of Leydig cells between the two populations can be inferred from the amount of hCG binding in fractions representing populations I (fractions 11-17) and II (fractions 20-24). Representative profiles of [ $\left.{ }^{125} \mathrm{I}\right] \mathrm{hCG}$ binding, expressed as femtomoles per testis, at 44 and at 55 days are illustrated in Figures 16 and 17, respectively. Figure 18 shows specific binding of $\left.{ }^{\left[{ }^{25}\right.} \mathrm{I}\right] \mathrm{hCG}$ in populations $\mathrm{I}$ and II obtained from completely dissociated testes of rats between 38 and 55 days of age. Between 38 and 44 days, the total number of Leydig cells per testis increased, as indicated by the increase in total binding of [ $\left.{ }^{125} \mathrm{I}\right] \mathrm{hCG}$. At both of these ages, the majority of 
Leydig cells were in population I. Between 44 and 55 days, the total number of Leydig cells remained approximately the same, but the number of Leydig cells in population I decreased, while the number in population II increased, so that in the mature animal the majority of Leydig cells were in population II. Since the total number of Leydig cells per testis, as indicated by total binding of $\left.{ }^{125} \mathrm{~T}\right] \mathrm{hCG}$, did not change between 44 and 55 days, the data shown in FIGURE 18 suggest that Leydig cells may shift from population I to population II during puberty. At present, factors that control this shift in relative abundance of Leydig cells from population I to population II are not known. Patterns of basal and hCG-stimulated androgen production in both populations of Leydig cells during sexual maturation are presently under investigation.

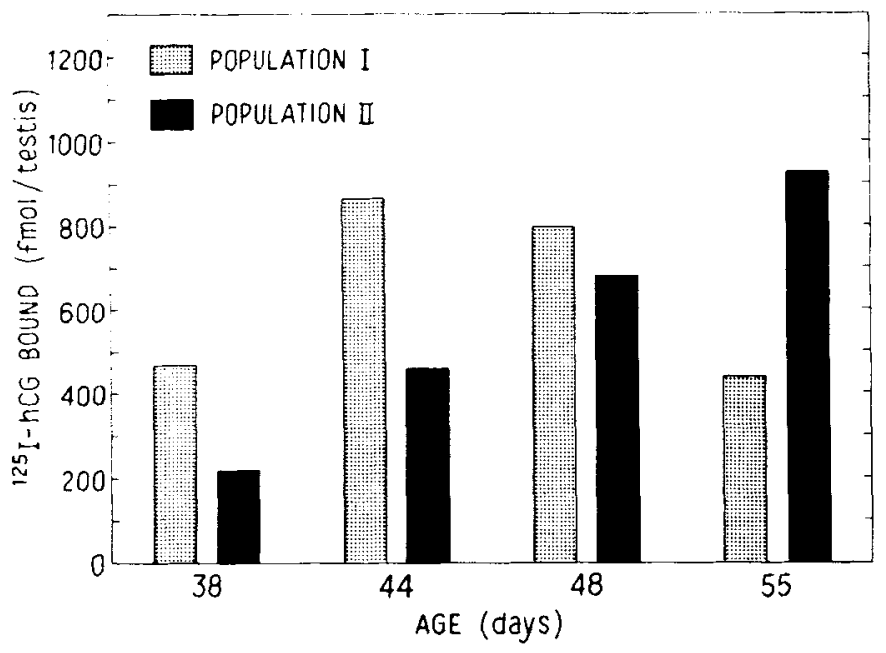

FIGURE 18. Binding of $\left[{ }^{195} I\right] h C G$ by population I and II Leydig cells from rats at various ages during puberty. Testes were completely dissociated as described in text, centrifuged in discontinuous Metrizamide gradients, and specific binding of $\left[{ }^{122} I\right] h C G$ to cells of individual fractions was determined, as described in the legend to FIGURE 1. Values for fractions 11-17 and fractions 20-24 were totaled to obtain values for population I and population II Leydig cells, respectively. Values were normalized to represent one testis at each age.

\section{Examination of Leydig Cells by Electron Microscopy}

Cells from completely dispersed testes were separated by centrifugation in discontinuous gradients of Metrizamide. One- $\mathrm{ml}$ fractions representing population I and population II, as described in the preceding section, were combined, fixed in suspension, centrifuged to collect the pellet of cells, and processed for electron microscopy. Based on developmental studies of the type described above, two ages were chosen to represent the two basic patterns of distribution of Leydig cells between the two populations. Electron micrographs of Leydig cell populations I and II from 38- and from 54-day-old animals indicated that the Leydig cells were intact and displayed the morphological characteristics described for rat Leydig cells. ${ }^{1 i,}{ }^{* *}$ As shown in FIGUREs 19-22, these characteristics include abundant smooth endoplasmic reticulum, occasional patches of rough endoplasmic reticulum, mitochondria with lamellar cristae, a prominent 

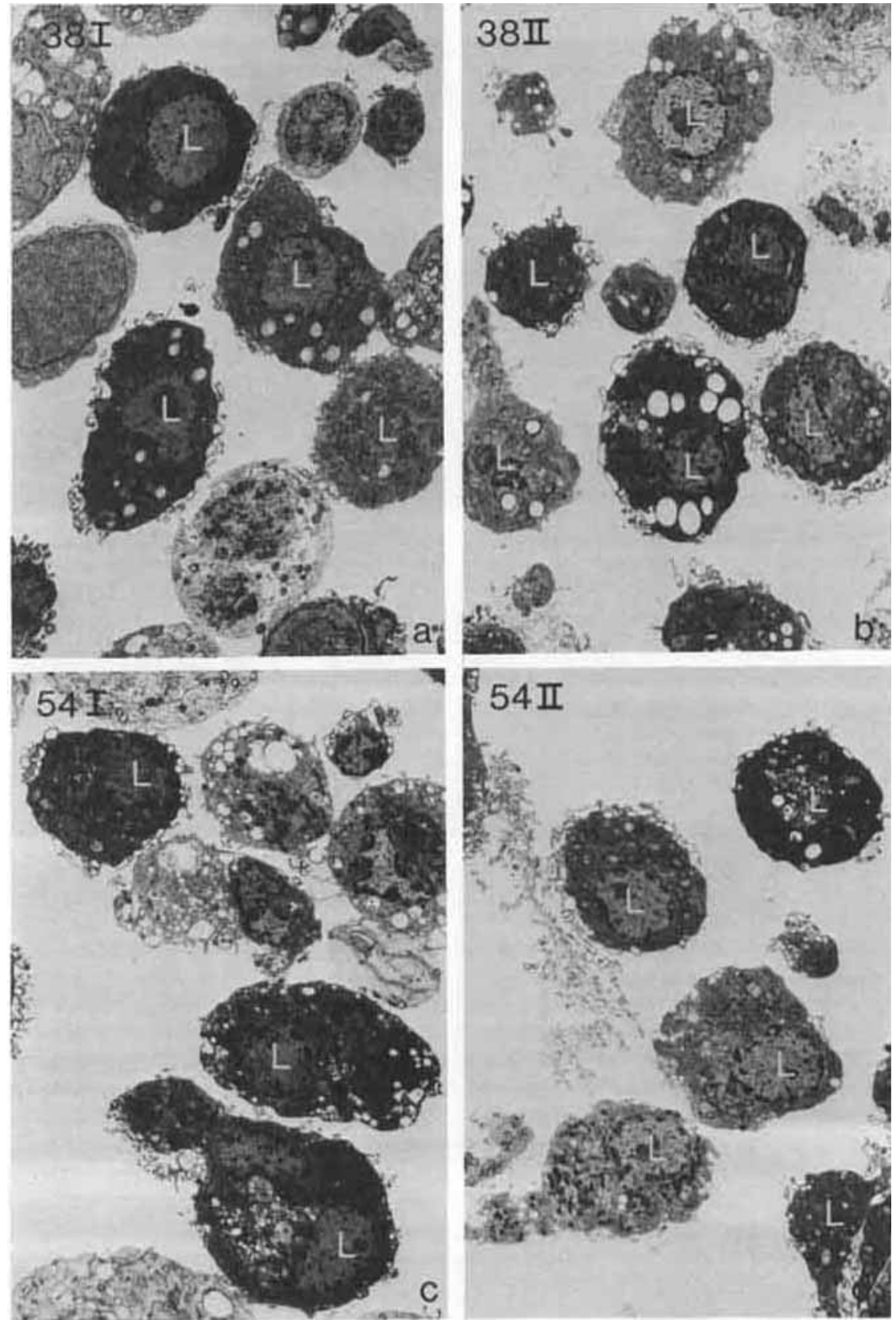

Figure 19. Low magnification electron micrographs of testicular cells from 38- and 54-day-old rat testes isolated by centrifugation in discontinuous Metrizamide gradients. Celis from fractions 12-16 were combined as population $I$ and cells from fractions 20-24 were combined as population II. The age of the rats and the population are indicated in each figure. Note that Leydig cells (L) in both populations at both ages appear to be intact. $(\times 2,475)$ 

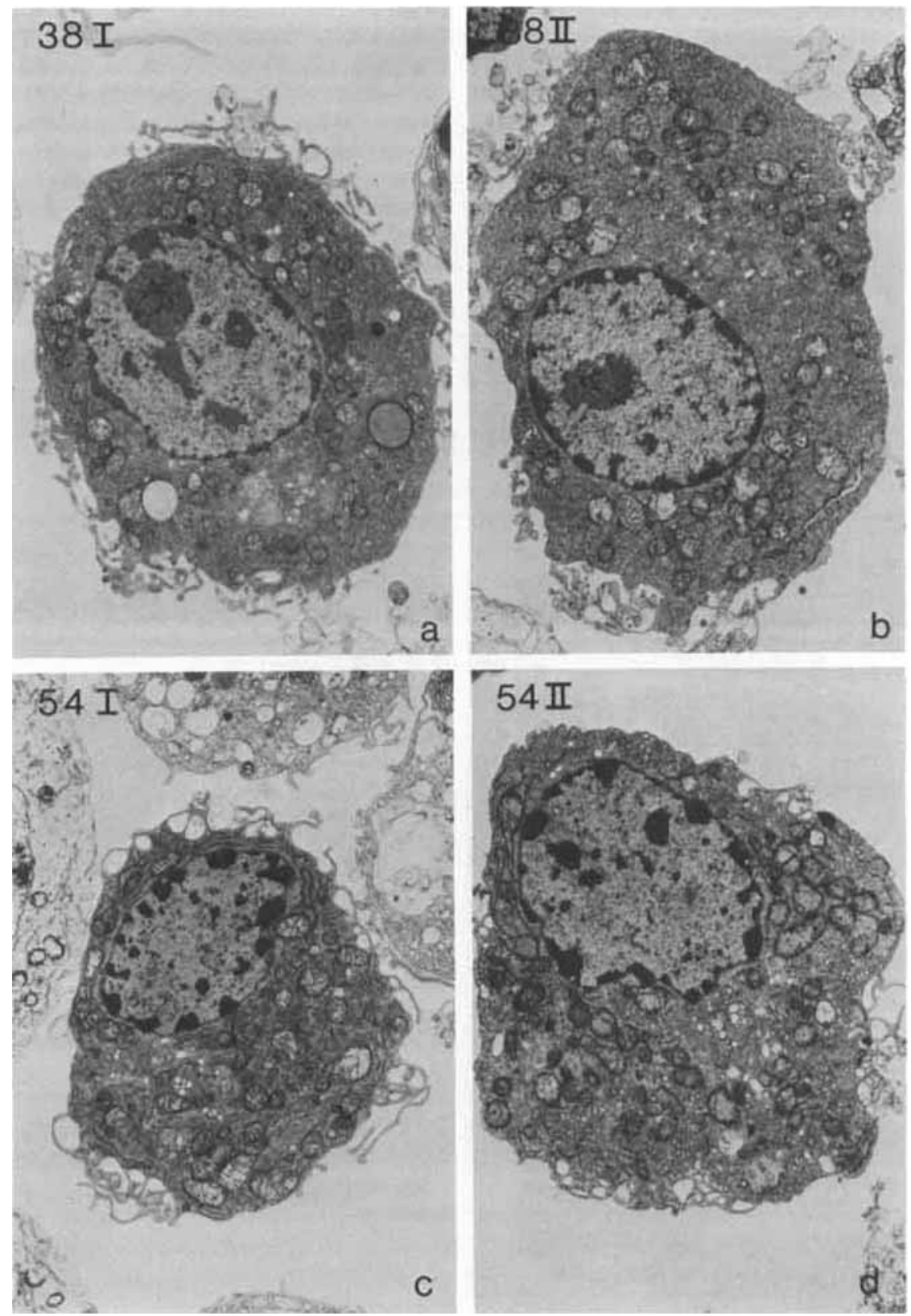

FIGURE 20. Electron micrographs of cells from 38- and 54-day-old rat testes isolated by centrifugation in discontinuous Metrizamide gradients. Fractions were combined as described in Figure 19. The age of the rats and the population are indicated in each figure. Evident from these micrographs is the maintenance of typical Leydig cell characteristics after gradient isolation. $(\times 5,460)$ 

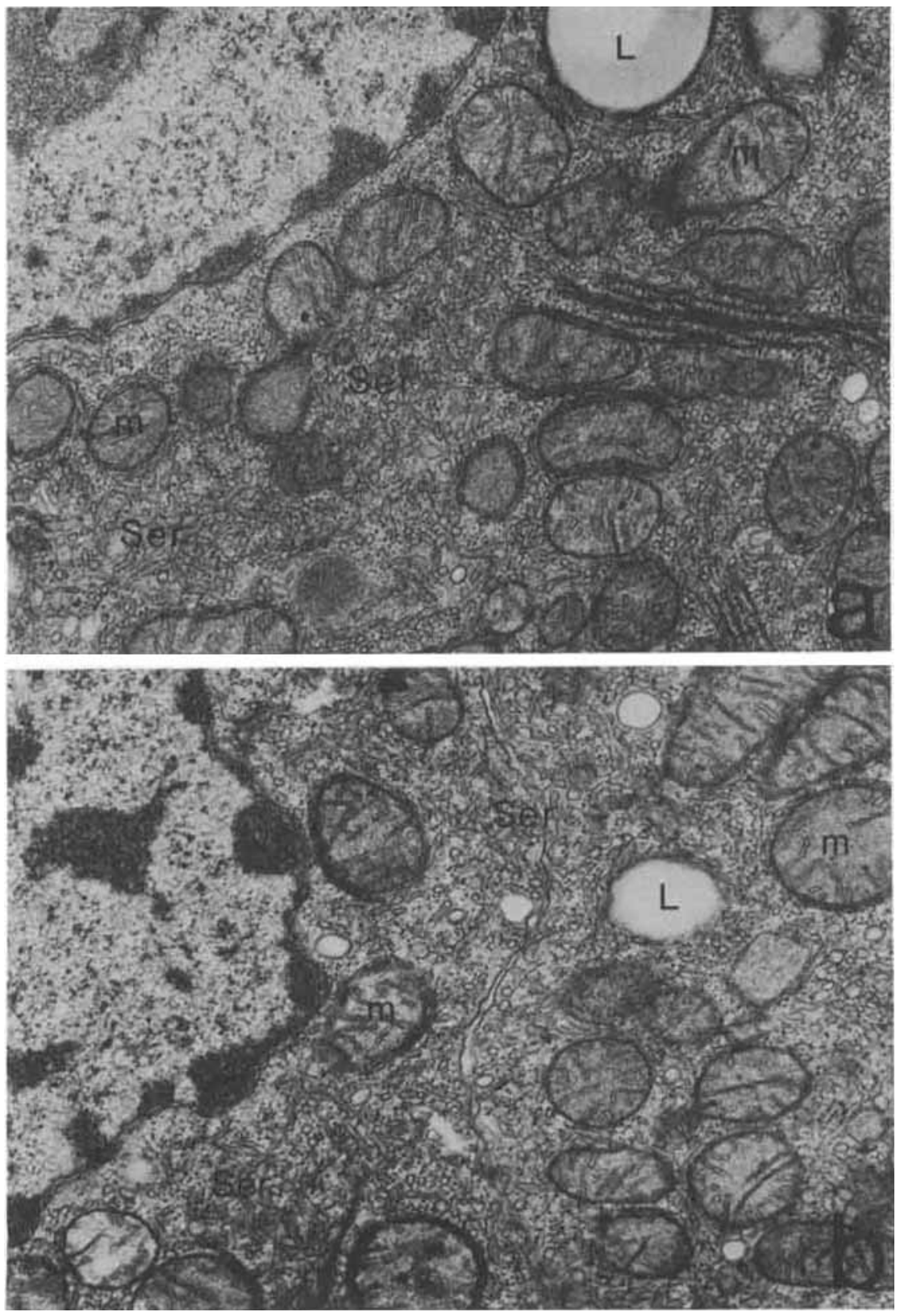

FIGURE 21. High magnification electron micrographs of Leydig cells from populations I (a) and II (b) from 38-day-old rats. These cells resemble those of intact testes in having abundant smooth endoplasmic reticulum (SER), numerous mitochondria $(\mathrm{M})$, and several lipid droplets $(\mathrm{L}) .(\times 24,750)$ 

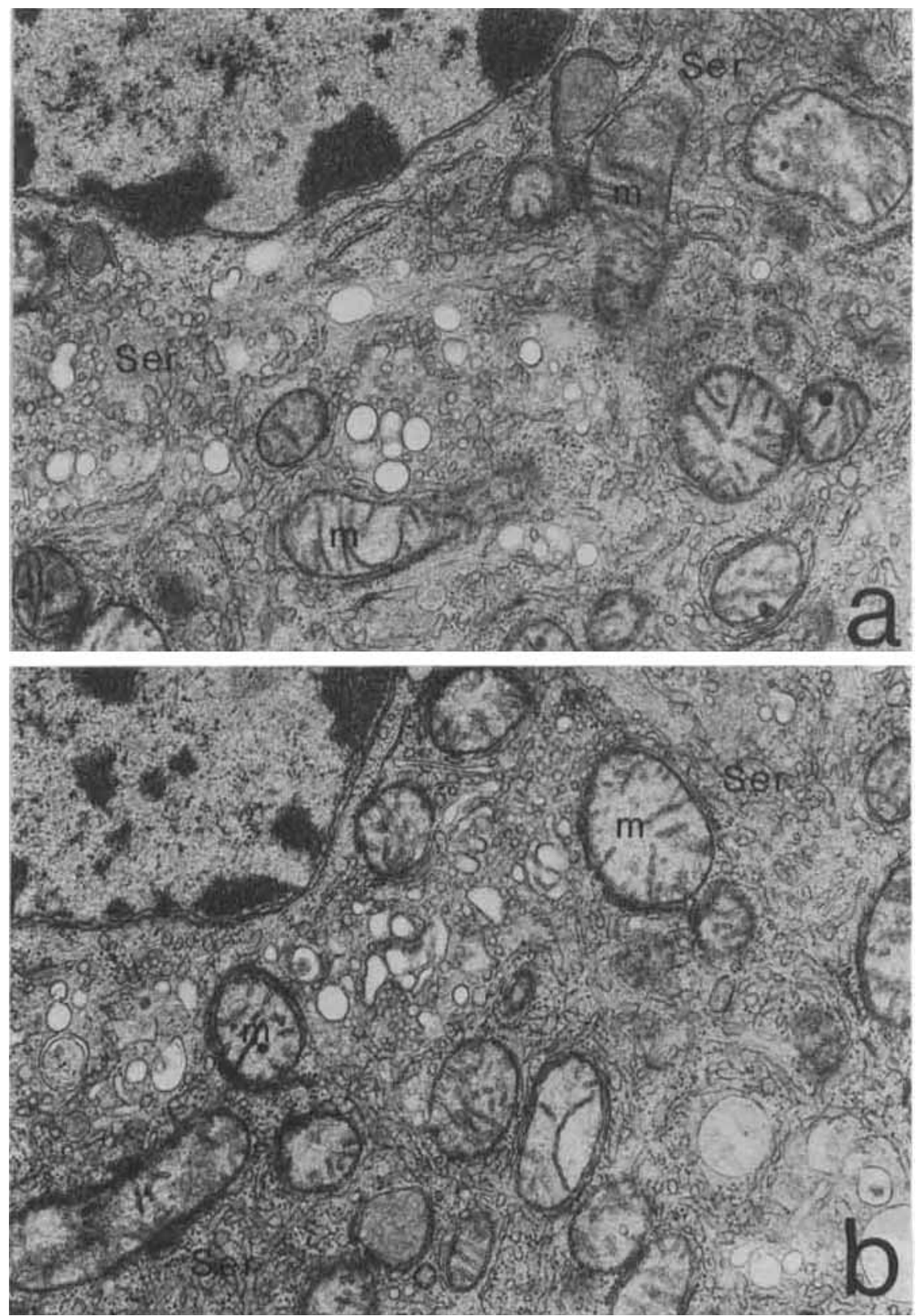

FIgure 22. High magnification electron micrographs of Leydig cells from populations I (a) and II (b) from 54-day-old rats. As in FIgURE 21, the cells show typical Leydig cell morphology with well developed smooth endoplasmic reticulum (SER) and numerous mitochondria (M). As in Leydig cells of intact mature testes, these Leydig cells contain relatively few lipid droplets. $(\times 24,750)$ 
Golgi apparatus, and a large ovoid nucleus with a thin rim of peripheral heterochromatin. Other common organelles include lysosomes, multivesicular bodies, and peroxisomes. Lipid droplets are also present but they are more numerous in Leydig cells from the immature animals (FIGUREs 20-22). Preliminary observations have not revealed any consistent differences in the morphology between the two populations at either age. However, more detailed morphological analyses are presently under way to determine if structural differences exist between the two populations that could explain the observed differences in responsiveness, in enzyme activity, and in sedimentation in Metrizamide gradients.

\section{REFERENCES}

1. ZIPF, W. B., A. H. PAYNe \& R. P. Kelch. 1978. Dissociation of lutropininduced loss of testicular lutropin receptors and lutropin-induced desensitization of testosterone synthesis. Biochim. Biophys. Acta 540:330-336.

2. Sharpe, R. M. 1976. hCG-induced decrease in availability of rat testis receptors. Nature 264:644-646.

3. Hsueh, A. J. W., M. L. Dufau \& K. J. CatT. 1976. Regulation of luteinizing hormone receptors in testicular interstitial cells by gonadotropin. Biochem. Biophys. Res. Commun. 72(3):1145-1152.

4. Hsueh, A. J. W., M. L. Dufau \& K. J. Catr. 1977. Gonadotropin-induced regulation of luteinizing hormone receptors and desensitization of testicular $3^{\prime}: 5^{\prime}$ cyclic AMP and testosterone responses. Proc. Natl. Acad. Sci. USA 74(2):592-595.

5. Purvis, K., P. A. Torjesen, E. Haug \& V. Hansson. 1977. hCG suppression of $\mathrm{LH}$ receptors and responsiveness of testicular tissue to hCG. Molec. Cell. Endocrinol. 8(1):73-80.

6. Tsuruhara, T., M. L. Dufau, S. Cigorraga \& K. J. Catt. 1977. Hormonal regulation of testicular luteinizing hormone receptors. J. Biol. Chem. 252(24); 9002-9009.

7. Saez, J. M., F. Haour \& A. M. Cathiard. 1978. Early hCG-induced desensitization in Leydig cells. Biochem. Biophys. Res. Commun. 81(2):552-558.

8. PAYne, A. H., J. R. Downing \& K.-L. Wong. 1980. Luteinizing hormone receptors and testosterone synthesis in two distinct populations of Leydig cells. Endocrinology 106(5):1424-1429.

9. Shaw, M. J., L. E. Georgopoulos \& A. H. Payne. 1979. Synergistic effect of follicle-stimulating hormone and luteinizing hormone on testicular $\Delta^{5}-3 \beta$ hydroxysteroid dehydrogenase-isomerase: application of a new method for the separation of testicular compartments. Endocrinology 104(4):912-918.

10. Payne, A. H., K.-L. Wong \& M. M. Vega. 1980. Differential effects of single and repeated administrations of gonadotropins on luteinizing hormone receptors and testosterone synthesis in two populations of Leydig cells. J. Biol. Chem. 255(15):7118-7122.

11. Dorrington, J. H., I. B. Fritz \& D. T. Armstrong. 1978. Control of testicular estrogen synthesis. Biol. Reprod. 18(1):55-64.

12. Valladares, L. E. \& A. H. Payne. 1979. Induction of testicular aromatization by luteinizing hormone in mature rats. Endocrinology 105(2):431-436.

13. Canick, J. A., A. Makris, G. L. Gunsalus \& K. J. Ryan. 1979. Testicular aromatization in immature rats-localization and stimulation after gonadotropin administration in vivo. Endocrinology 104(2):285-288.

14. Valladares, L. E. \& A. H. Payne. 1979. Acute stimulation of aromatization in Leydig cells by human chorionic gonadotropin in vitro. Proc. Natl. Acad. Sci. USA 76(9):4460-4463. 
15. Ciggorraga, S. B., S. Sorrel, J. Bator, K. J. Catt \& M. L. Dufau. 1980. Estrogen dependence of a gonadotropin-induced steroidogenic lesion in rat testicular Leydig cells. J. Clin. Invest. 65(3):699-705.

16. Nozu, K., M. L. Dufau \& K. J. CATT. 1981. Estradiol receptor-mediated regulation of steroidogenesis in gonadotropin-desensitized Leydig cells. J. Biol. Chem. 256(4):1915-1922.

17. Christensen, A. K. 1975. Leydig cells. Handb. Physiol. 5:57-94.

18. Christensen, A. K. \& S. W. Gillim. 1969. Correlation of fine structure and function in steroid secreting cells, with emphasis on those of the gonads. In The Gonads. K. W. Mc. Kerns, Ed.:415-488. Appleton-Century-Crofts. New York, N.Y.

19. Zirkin, B. R., L. L. Ewing, M. Kromann \& R. C. Cochran. 1980. Testosterone secretion by rat, rabbit, guinea pig, dog and hamster testes perfused in vitro: correlation with Leydig cell ultrastructure. Endocrinology 107(6): $1867-1874$.

20. Murono, E. P. \& A. H. Payne. 1976. Distinct testicular 17-ketosteroid reductases, one in interstitial tissue and one in seminiferous tubules. Differential modulation by testosterone and metabolites of testosterone. Biochim. Biophys. Acta 450:89-100.

21. Payne, A. H., R. P. Kelch, E. P. Murono \& J. J. Kerlan. 1977. Hypothalamic, pituitary and testicular function during sexual maturation of the male rat. J. Endocrinol. 72(1):17-26.

22. Goldman, A. S. \& D. A. Klingele. 1974. Developmental defects of testicular morphology and steroidogenesis in the male rat pseudohermaphrodite and response to testosterone and dihydrotestosterone. Endocrinology 94(1):1-16.

23. O'Shaughnessy, P. J., K.-L. Wong \& A. H. Payne. 1981. Differential steroidogenic enzyme activities in different populations of Leydig cells. Endocrinology 109(4): 1061-1066.

\section{Discussion OF THE PAPER}

J. A. Dias (Albany Medical College, Albany, N.Y.): Dr. Payne, you mentioned that the receptor number per cell in the two populations was not different as animals age. Was the receptor affinity different?

PAYNe: We've tested affinity only in the adults so far, so there is still a possibility that the affinity is different in young animals.

Dias: It would be worth checking because small differences in affinity could explain the differences in total binding that you saw between the two Leydig cell populations. The conclusion that you are drawing from the study is that there are different numbers of Leydig cells in the two populations.

PAYNE: It obviously has to be studied further.

Dias: Have you analyzed the membranes of the two populations to see if the lipid constituency to the membrane types are different?

PAYNe: No.

Dias: From our studies with detergent-solubilized receptors, if lipids do play a role, steroid biogenesis in the two different cell populations may indicate differences in lipid turnover in the membrane, such as the transfer of cholesterol through the membranes. It may be worth looking at steroid biogenesis to see whether the lipid composition of the two cell populations is different. It may also explain some differences in the nature of your sedimentation experiments.

PAYNE: We definitely plan to do that. 
F. ROMMERTS (Erasmus University, Rotterdam, the Netherlands): What do you think is the basis for the separation of the cell populations?

PAYNE: The differences could be due to density, size, or shape. At this point I don't think we can tell until we have more data.

ROMMERTS: Then if we still don't know their properties we should be very cautious about calling the cell a Leydig cell. The properties of the Leydig cells have not been clearly defined. For instance, we have shown in culture that you can have cells which have no $3 \beta$-ol-dehydrogenase activity but still respond to LH with cleavage of cholesterol. There are other data where marker activities, which have been assigned to Leydig cells, are not always present.

PAYNE: Certainly our cells have the morphological characteristics of Leydig cells in each population. We've never seen an autoradiograph of any cell that stained positively for $3 \beta$-ol that did not show grains due to specific binding of $\left.{ }^{125} I\right]$ hCG. They may have different activities of $3 \beta$-hydroxy-steroid dehydrogenase and they may stain differently in intensity. But we really have no evidence that there are Leydig cells that don't contain $3 \beta$-hydroxysteroid dehydrogenase but that can produce testosterone. It would be pretty difficult. I don't see how they could.

A. DeHEJIA (National Institutes of Health, Bethesda, Md.): We've been interested in using purified Leydig cells to study steroidogenesis and gonadotropin receptors. We use 14 to $32 \%$ Metrizamide gradients to separate collagenase-dispersed interstitial tissue and get five visibly distinct bands. Bands $1,2,3$, and 4 represent peaks of NBT (nitroblue tetrazolium) staining when we fractionate and measure $3 \beta$ hydroxy-steroid dehydrogenase activity. Band 5 consists entirely of red blood cells and shows no NBT-staining activity. Testosterone production in bands 3 and 4 is roughly three-fold greater than that of Band 2. When we pretreated the cells with iodinated hCG, we get binding peaks in bands 3 and 4, twice as high as that of band 2 .

PAYNE: Is this binding expressed per $3 \beta$-hydroxy-steroid-positive cells?

DeheJIA: Yes. Bands 3 and 4 were combined and compared with band 2 . We obtained cell pellets from each layer and prepared light microscopic autoradiographs. Most of the cells in bands 3 and 4 have grains around them whereas, in the heterogeneous layer (band 2) only a few cells show bound grains. From electron micrographs of the purified layer, the Leydig cells show mitochondria and the cytoplasm is densely packed with smooth endoplasmic reticulum, which correlates with steroidogenic ability. We find that lymphocytes occasionally bind to the Leydig cells and migrate with them.

PAYNE: I don't think we know how to compare our fractions to yours because we use a very different type of gradient and all I can say is that our population I does not respond as well. There are no obvious morphological differences in regard to smooth ER or mitochondria. But maybe your band 1 and my population I are different.

DEHEJIA: I think your population I probably corresponds to our band 2 .

K. J. CatT (National Institutes of Health, Bethesda, Md.): What does seem to be similar in these two situations is that the bands 3 and 4 may correspond to your bands $1 \mathrm{~B}$ and 2 .

PAYNe: Very possible.

RobaIre ( $M c$ Gill University, Montreal, Que.): Have you done anything that will change your ratio of II to I?

PaYne: No. The distribution, as regards binding, is a very recent finding. We haven't manipulated the system yet. 
ROBAIRE: If the difference between population I and II is simply a question of the degree to which those cells are stimulated and the difference in sedimentation, simply a reflection of the amount of smooth ER, then you really don't have two populations but a continuum of populations.

PAYNE: That is very possible. I think there could very well be a continuum of one population especially bands $1 \mathrm{~A}$ and $1 \mathrm{~B}$.

RoBAIRE: The amount that you get of any cell depends entirely on the state of the animal, which would fit with your developmental data.

PaYne: As I said, I don't know the factors that control this apparent change from population I to II and we certainly have to look into whether it's controlled by hormonal stimulation.

M. L. Dufau (National Institutes of Health, Bethesda, Md.): Have you examined desensitization with these new conditions?

PaYne: We have not gone back and re-examined the effect of desensitization using the new gradient.

Dufau: Therefore, it seems likely that your $1 \mathrm{~B}$ population corresponds to our number 3 and 4 population and is likely to have the same desensitization as your 1 and 2 .

PAYNe: That's very possibie. The major point I wish to emphasize in regard to desensitization is that the effect of exogenous $\mathbf{L H}$ on Leydig cell steroidogenesis depends upon whether steroidogenic response is examined after administration of a single, high dose of LH (which does not occur under any physiological or pathological conditions) or after multiple daily injections of LH.

There is also a difference between hCG, the latter has a much longer halflife than LH. I don't think we can say that hCG is comparable to what really occurs in vivo with LH.

V. Hansson (Rikshospitalet, Oslo, Norway): Drs. Purvis and Claussen in Oslo have looked at the correlation between LH receptor binding by autoradiography and $3 \beta$-hydroxysteroid dehydrogenase (3 $\beta$-HSD). Below 20 days of age only $10-15 \%$ of Leydig cells actually show $3 \beta-$ HSD reaction, which gradually increases to $100 \%$ around day 50 , and then drops again after age 60 . $3 \beta$-HSD activity alone may not demonstrate all the Leydig cells because you have a threshold for the enzyme activity. Population II only had half the $3 \beta$-HSD activity of population I. You could ask the question, do they have the same binding, or have you in population II only recorded half of the Leydig cells because of the threshold with your $3 \beta$-HSD cytochemistry?

PAYNE: I could not have looked at only half, because $90 \%$ of all the cells in population II stained positively. As far as binding per Leydig cell, after age 25 there certainly is a marked difference in binding per Leydig cell compared to animals that are younger. We are not looking at difference in intensity, we are looking at positive staining and comparing that to the binding. We don't see cells that concentrate grains that don't stain positive for $3 \beta$-hydroxy-steroid dehydrogenase.

M. Ascoli (Vanderbilt University, Nashville, Tenn.): How do you know whether population $1 \mathrm{~B}$ isn't $1 \mathrm{~A}$ and II?

PAYNE: We do believe population $1 \mathrm{~B}$ is not a mixture of $1 \mathrm{~A}$ and population II Leydig cells because we have recentrifuged population 1B in a 0 to $40 \%$ continuous gradient and couldn't demonstrate that.

B. P. SEtChell (A.R.C. Institute of Animal Physiology, Cambridge, England): In your comparison of the single large injection and the multiple 
injection you compared data after six days of multiple injections versus three days after single large injections. Have you done a more direct comparison of cells obtained after three days of single large injections and three days of multiple injections? Or seven days after multiple and single large injections?

PAYNE: Yes, we have. In in vivo studies we have followed Leydig cell responses with twice-daily injections over a ten-day period, measured first at three days. There was a time-related increase in responsiveness over the ten day period; while with a single subcutaneous injection the maximum decrease in receptors and in responsiveness was observed between two and three days. The response increased after three days and returned to normal by five days. At 72 hours, we observe the maximum decrease in both $\mathbf{L H}$ receptor and testosterone concentration.

B. A. Cooke (London University, London, England): I'd just like to interject a word of caution on the way we're preparing the cells and the way we're separating them. Using Metrizamide, which I have never been very happy with, it's possible to get damaged cells. Schumacher and Hilz have shown that Metrizamide will damage mouse Leydig cells. Leydig cell populations seem to be much higher than we would think using different media. Using different media we consistently get active Leydig cells in your band II, at a density of about 1.07 and this is consistently lower than any of the other reported densities.

PAYNE: I'm only reporting the density of the Metrizamide solution where these Leydig cells are found and I don't know the density of these Leydig cells.

CooKe: Mechanical dispersion can completely destroy the steroidogenic potential of the Leydig cells, although they still have $\mathrm{LH}$ receptors. We've recently been using Percoll to separate mouse Leydig cells and get a very distinct band of responsive cells. Within that band we find some heterogeneity but they don't separate out into two distinct populations. Rather there's a whole range of activities described by $3 \beta$-dehydrogenase in response to $L H$. From rats using Percoll, we also get two populations, but again it seems as if it is a whole range of activities rather than two distinct populations.

PAYNE: It could be a range but I still feel that populations II and I are different. Population I is sort of a range of different types of Leydig cells. Obviously we have to do more studies to get this all sorted out.

T. LIN (University of South Carolina, Columbia, S.C.): Recently we also found two distinct populations of Leydig cells in 24-month-old rats. Interestingly, both populations respond to $\mathrm{LH}$ stimulation with increased cyclic AMP production, but only population II may have increased testosterone production.

A. Rivenson (American Health Foundation, Valhalla, N.Y.): Dr. Dehejia mentioned that lymphocytes are occasionally attached to Leydig cells. Lymphocytes actually attach to Leydig cells as a rule. If we combine suspensions of Leydig cells and lymphocytes, B-lymphocytes or T-lymphocytes, we obtain beautifully formed rosettes. The only requirement is not to use enzymes to disperse the Leydig cells because we remove the receptors from the membrane. We can separate two populations of Leydig cells, one population forming rosettes, that means having receptors for lymphocytes and another smaller population not having this type of receptors.

PAYNe: To protect against destruction of receptors, we've been adding $1.5 \%$ BSA. If you use concentrations of collagenase higher than 0.25 milligrams per $\mathrm{ml}$ you start seeing destruction of $\mathrm{LH}$ receptor sites. There is a difference in sensitivity in the two populations. 